\title{
Growth and decay of a marine terminating sector of the last British-Irish Ice Sheet: a geomorphological reconstruction
}

\author{
Andrew Finlayson ${ }^{\mathrm{a}, \mathrm{c}, *}$, Derek Fabel $^{\mathrm{b}}$, Tom Bradwell ${ }^{\mathrm{a}}$, David Sugden ${ }^{\mathrm{c}}$ \\ ${ }^{a}$ British Geological Survey, Murchison House, West Mains Road, Edinburgh, EH93LA, UK \\ ${ }^{b}$ Department of Geographical and Earth Sciences, University of Glasgow, Glasgow, G128QQ, UK \\ ${ }^{c}$ Institute of Geography, University of Edinburgh, Drummond Street, Edinburgh, EH89XP, UK
}

\begin{abstract}
The boundary conditions that govern ice sheet dynamics can change significantly with the development of marine margins. This paper uses the glacial landscape in western Scotland to reconstruct changes in the British-Irish Ice Sheet that accompanied the growth and decay of a marine sector over the Malin Shelf. Ice advanced from a restricted mountain ice sheet with tidewater margins after $\sim 35 \mathrm{ka} \mathrm{BP}$, and reached the continental shelf in $\sim 7 \mathrm{ka}$ (average rate of $\sim 30 \mathrm{~m} \mathrm{a}^{-1}$ ). Early ice flow had been directed through northsouth, geologically controlled, over-deepened fjords that were carved during previous 'restricted' glaciations. This flow regime was abandoned with development of the Malin Shelf ice sheet sector; ice flow direction switched by $\sim 90^{\circ}$ and was drawn westwards towards the shelf edge. The marine ice sheet phase saw episodes of west-east ice divide migration by up to $60 \mathrm{~km}$ over west central Scotland, possibly linked to ice streaming and calving events at the ice sheet margin. However, permanent and stationary ice divides and zones of cold-based ice, associated with subglacial topographic highs, also characterised the marine glacial stage over western Scotland. The North Channel ice divide remained a constant, though migratory feature while the BIIS occupied the Malin Shelf; it finally collapsed at the end of the Killard Point Stadial when the Irish Ice Sheet began to rapidly decay $\sim 16.5 \mathrm{ka}$ BP. This permitted the Scottish Ice Sheet to temporarily advance over north-east Ireland (previously identified as the East Antrim Coastal Readvance) before it too retreated, at rates in the order of $10^{2} \mathrm{~m} \mathrm{a}^{-1}$. Although the imprint of extensive shelf-edge ice sheet glaciation exists in the coastal landscape of western Scotland, the dominant landscape features relate to a restricted, marine-proximal mountain ice sheet with markedly different flow configurations. Similar first-order geomorphological features, relating to 'restricted' glacial conditions, are likely to be preserved in subglacial highlands under interior parts of modern ice sheets.
\end{abstract}

\section{Introduction}

The geological record left by past ice sheets provides information about their long-term evolution and interaction with the landscape over timescales beyond that of contemporary glaciological observations (Boulton and Clark, 1990; Kleman et al., 2008, 2010). Large-scale ice sheet reorganisations identified in palaeoglaciological studies therefore add important context to recent changes seen in modern ice sheets (Retzlaff and Bentley, 1993; Conway et al., 2002), and can play a role in

\footnotetext{
${ }^{*}$ Corresponding author

Email addresses: afin@bgs.ac.uk (Andrew Finlayson), Derek.Fabel@glasgow.ac.uk (Derek Fabel), tbrad@bgs.ac.uk (Tom Bradwell), David.Sugden@ed.ac.uk (David Sugden)
} 
predicting their future evolution as we discover more about the landscapes they submerge (Ross et al., 2012). Parts of the West Antarctic Ice Sheet (WAIS), for example, rest on complex topography, with deep basins in close proximity to subglacial highlands, which have been suggested to possess characteristics of former marine-proximal alpine glaciation (e.g. the Ellsworth Subglacial Highlands) (Holt et al. 2006; Vaughan et al. 2006; Ross et al. in press). Linking these new findings about the subglacial topographic setting of the WAIS with longer-term $\left(10^{4} \mathrm{yr}\right)$ ice sheet dynamics is an exciting area of research, and one in which insights from former ice sheets can contribute.

The BIIS is known to have had marine or partially marine sectors, which have been suggested to be analogous to parts of the present West Antarctic Ice Sheet, although smaller in scale (Bradwell et al., 2008; Graham et al., 2009; Clark et al., 2012). Recent systematic assessments utilising high-resolution elevation datasets, have considerably advanced our understanding of the overall configuration and flow paths during retreat of the BIIS (Clark et al., 2012). However, detailed time transgressive reconstructions of flow geometries and configurations during ice sheet build up and collapse do not yet exist for a number of important ice sheet sectors. Comprehensive investigations combining remote-sensing- and field-based investigations (eg. Livingstone et al., 2009) can provide this information and reveal how an evolving ice sheet interacted with its bed (e.g. Sugden, 1968; Hall and Sugden, 1987; Kleman and Glasser, 2007; Golledge et al., 2009), thereby providing a key link between long-term ice dynamics and the subglacial landscape.

In this paper we examine the geomorphological record from the peninsula of Kintyre and the adjacent island of Arran (combined area of $\sim 825 \mathrm{~km}^{2}$ ) at the transition between the fjord-like coastal terrain of the western Scottish Highlands and the Malin Shelf to the west (Figs. 1,2), in order to reconstruct BIIS behaviour through the last glacial cycle. The area is ideally suited for detailed palaeoglaciological examination since: (i) the position of western edge of the BIIS meant that it was particularly sensitive to changes in oceanic and atmospheric circulation that characterised the North Atlantic region during the last glacial cycle (Rahmstorff, 2002; McCabe, 2008); (ii) Kintyre and Arran contain a variety of landforms and sediments, some of which have been suggested to pre-date the growth of the last ice sheet, therefore providing insight into the extent of landscape modification that took place during the last glacial cycle; (iii) the southernmost point of Kintyre, the Mull of Kintyre, lies just $20 \mathrm{~km}$ from the Irish mainland, providing a unique link between the terrestrial geomorphological records of south-west Scotland and north-east Ireland, 
with the potential to greatly improve our understanding of the break up of the BIIS over the North Channel; and (iv) published data exist for adjacent parts of the BIIS (e.g. Greenwood and Clark, 2009; Finlayson et al., 2010; Dunlop et al., 2010; McCabe and Williams, 2012), which can be combined in a larger-scale synthesis of the advance and collapse its western margin. Despite these research opportunities, Kintyre and Arran have received little recent geomorphological examination in relation to the BIIS. The goal of this paper, therefore, is to review and re-examine the glacial geomorphology of Kintyre and Arran, and combine new data with published studies to examine the nature and scale of changes in the BIIS associated with the growth and decay its western marine margin.

\section{Setting}

\subsection{Geology and relief}

Kintyre is a 68-km-long, north-south trending peninsula in the south-west of Scotland (Figs. 1,2). It is no more than $19 \mathrm{~km}$ wide at any point and is bounded to the west by the Sound of Jura (200 m below sea level (b.s.l.)), to the east by the Kilbrannan Sound (120 m b.s.l.), part of the outer Firth of Clyde, and to the south by the North Channel, a tectonic basin up to $300 \mathrm{~m}$ b.s.l. (Maddox et al., 1993). West Loch Tarbert separates Kintyre from the Knapdale region to the north. Most of the solid rocks underlying Kintyre consist of psammites, semipelites and pelites belonging to the Dalradian Supergroup. In central- and north-western parts of Kintyre, these rocks possess a broad north-south trending strike, which is visible on digital surface models (Fig. 3). The central spine of the peninsula generally ranges between $100 \mathrm{~m}$ and $450 \mathrm{~m}$ above sea level (a.s.l.) in elevation. It is separated by a low-lying corridor, 10-50 m a.s.l., between Campbeltown Loch and Machrihanish Bay, where the underlying rocks consist of Carboniferous sandstones and lavas. Devonian conglomerate is present under the south-eastern corner of the peninsula and outcrops of Permian sandstone are present along parts of the western coastline, both resting unconformably on the underlying Dalradian rocks.

The Island of Arran $\left(435 \mathrm{~km}^{2}\right)$ is separated from Kintyre by the Kilbrannan Sound and bounded to the east by the North-east Arran Trough (170 m b.s.l.)(Figs 1, 2). The northern half of the island is dominated by the Northern Granite Pluton, which was intruded into Dalradian metasediments and Devonian sandstones during the Tertiary Period. The pluton comprises an outer coarse- 
grained granite and an inner fine-grained granite. It now forms an elevated massif, which is alpine in character with steep-sided corries, valleys and arêtes, and several summits that exceed $700 \mathrm{~m}$ - the highest being Goatfell $(874 \mathrm{~m})$. These northern hills are surrounded by a well-developed surface at approximately $300 \mathrm{~m}$ in elevation, known as the 'Thousand Foot Platform' (Tyrrell, 1928). This surface, which crosses geological boundaries, possesses immature drainage, and is cut by glaciated valleys, has been suggested to be part of a preglacial, possibly Pliocene age, plateau (Gregory, 1926; Tyrrell, 1928). The bedrock surface on the southern half of the island principally comprises Devonian, Permian and Triassic sandstones, with a smaller central granitic intrusion and numerous sill complexes. In the south of the island the relief rarely exceeds $400 \mathrm{~m}$ in elevation.

\subsection{Glacial history}

\subsubsection{Pre-Main Late Devensian sediments and landforms}

Sediments and landforms, which have been interpreted to pre-date the last major glacial cycle (the Main Late Devensian (MLD), Marine Isotope Stage 2, Greenland Stadial 5-1 (Lowe et al., 2008)) have been reported from Kintyre. Shell-bearing clays underlie till at three sites in and around Tangy Glen (Fig. 2) on the west coast (Horne et al. 1896). These clays, found at elevations of between 40 and $60 \mathrm{~m}$ a.s.l., were reported to contain molluscs, ostracods and forams indicative of both arctic and warmer temperate environments, and were argued by Munthe (1897) to record a period of deposition spanning a glacial-interglacial-glacial transition. The shelly clays have subsequently been interpreted as being either in situ remnants of Middle Quaternary marine deposits from a period of significantly higher relative sea levels (Sutherland, 1981), or emplaced as a glacial raft by the advancing MLD ice sheet (Synge and Stephens, 1966). A rock platform at 13 m a.s.l. also exists underneath till at Glenacardoch Point on the west coast (Sinclair, 1911; Gray, 1978). The platform is one of the few sites in Scotland where low-level shore platforms have been seen to pass beneath till, and it has been suggested to relate to an interglacial period pre-dating the last glacial cycle (Sissons, 1981; Gray, 1993).

Deposits containing both cold and warm water shells have also been discovered under and within till in the south of Arran, at elevations up to $55 \mathrm{~m}$ a.s.l. (Watson, 1864; Bryce, 1865). Sutherland (1981) argued that the shell beds cannot have been transported glacially and are largely in situ, because they are present in an area where ice flow indicators on the land surface show that the last ice movement was towards, not from, the sea. However, an in situ interpretation is not 
consistent with the original descriptions of the sediments by Watson (1864), who wrote that, "the layers of sand curve sharply upon themselves, as if they had been thrust forwards under a heavy weight from behind, and forced to over-ride one another'. Furthermore, recent MLD ice sheet reconstructions depict a stage of west-north-westward ice flow, presenting at least one possible mechanism for the transport of sediments from the sea across the southern edge of Arran (Salt and Evans, 2004; Finlayson et al., 2010; Livingstone et al., 2012).

\subsubsection{The Late Devensian glacial cycle (MIS 2)}

Early research on Kintyre used erratic dispersal patterns and glacial striae to recognise that the peninsula had been predominantly overridden by ice flowing westward towards the Malin Shelf during the MLD (Horne et al., 1896; Geological Survey of Scotland, 1913). Synge and Stephens (1966) suggested that this westerly flow was preceded by an advance from the north, presumably directed along the deep rock basins of the Sound of Jura and Kilbranan Sound, which had 'plugged' Tangy Glen with the shelly deposits. These authors also considered the final movement of ice on Kintyre to have been north to south, proposing that a former ice limit formed 'thick morainic accumulations' near Kilchenzie on the west coast. A general north to south pattern of ice movement through the Kilbrannan Sound and Firth of Clyde is also evident from striae on Arran, although this flow was diverted around the high ground where an independent ice dome was nourished during the MLD (Tyrrell, 1928; Gemmell, 1973).

There are no available dates from Kintyre to constrain the timing of deglaciation. However, dated samples obtained from sediment cores in surrounding marine waters indicate that postglacial sediment accumulation had begun by 13.1 - $12.7{ }^{14} \mathrm{C}(14.9$ - 14.5 cal) ka BP (Peacock, 2008; Peacock et al., 2012) (Fig. 1). McCabe and Williams (2012) have recently proposed that deglaciation of the western central zone of the last BIIS was punctuated by a major 'North Channel Readvance', c. 15-15.5 cal ka BP, which they suggest formed coeval moraines in East Antrim, Stranraer, and the Ayrshire and Clyde basins (Fig. 1). These authors envisaged general westward or south-westward ice flow over Kintyre at that time. No subsequent glacier margin readvances or stillstands have been identified on Kintyre. However, two subsequent advances of locally-nourished glaciers took place on Arran, the latter during the Younger Dryas (12.9-11.5 ka BP) (Ballantyne, 2007). 


\section{Methods}

A combined remote sensing and field-based approach was employed to characterise the subglacial and ice marginal geomorphological assemblages on Kintyre and Arran. In order to refine the deglacial chronology in the area, ice marginal landform assemblages were sampled for cosmogenic dating.

\subsection{Remote sensing evidence}

Glacial landforms were mapped within a Geographical Information System (GIS), using a combination of hill-shaded surface models (DSMs) derived from the NextMap Britain elevation dataset, georeferenced 1:10,000 scale, colour aerial photographs, and offshore bathymetry from the BGS Digbath-250 dataset. The NEXTMap Britain DSM has a $1.5 \mathrm{~m}$ vertical and $5 \mathrm{~m}$ horizontal resolution and was viewed at scales ranging from 1:10,000 to 1:100,000. A sub-sampled version of the DSM, with a horizontal resolution of $50 \mathrm{~m}$ was also used for investigation at scales of greater than 1:100,000. The DSMs were illuminated from both the north-west and north-east in an attempt to reduce the effects of azimuth biasing (Smith and Clark, 2005). The landforms that were recorded during the remote sensing survey include: major rock basins and troughs, streamlined bedforms, eskers, meltwater channels, moraines, and deltas. The presence and general trend of bedrock structures at the land surface were also noted as a crude indicator for the presence of sediment cover, and for its orientation relation relative to streamlined bedforms.

\subsection{Field evidence}

Field mapping was carried out on Kintyre and parts of Arran in 2010, using a ruggedized tablet PC with a built-in GPS and GIS software. The field mapping enabled verification of landforms identified during the remote sensing survey and helped identify smaller features that were not visible using the remote sensing datasets, such as tors, glacial erratics, and smaller moraines. Natural sections were also logged during the field investigation.

\subsection{Compilation and utilisation of geomorphological data}

All features observed during the remote sensing and field investigations were captured within a spatially attributed GIS database. Trommelen et al. (2012) highlighted the importance of integrating remotely-sensed and field-based geomorphological data in their Glacial Terrain Zone approach. 
This is particularly true when dealing with fragmented palaeoglaciological records, such as those found elsewhere in western Scotland (Salt and Evans, 2004; Finlayson et al., 2010). The data were collectively used to infer different glaciological conditions based on established process-form relationships. This 'inversion' approach is a well-established tool in palaeoglaciological reconstruction (Kleman and Borgstrőm, 1996; Kleman et al., 1997; Stokes et al., 2009). Landforms and sediments that were produced, or survived, under the ice -sheet allow inferences to be made about the action of the ice sheet on its bed. Consistently aligned clusters of streamlined bedforms may be grouped as 'flow sets' and used to infer episodes of warm-based ice sheet motion in a particular direction (Boulton and Clark, 1990; Kleman et al., 1997; Livingstone et al., 2009; Stokes et al., 2009). Marginal landforms such as moraines and meltwater channels can be used to interpret patterns of ice margin retreat (Clark et al., 2012).

\subsection{Cosmogenic nuclide analysis}

A number of radiocarbon ages constrain the deglaciation chronology in the inner Firth of Clyde (Hughes et al., 2011) (Fig. 1). However, fewer ages constrain the timing of deglaciation in the outer Firth of Clyde, and in particular, the decay of ice across the North Channel. In an attempt to improve chronological constraints on deglaciation, boulders from Glen Dougarie in western Arran and Glen Lussa in eastern Kintyre were sampled for cosmogenic nuclide analyses (Fig. 2). In Glen Dougarie, two granite erratics from the top of two linked broad lateral moraines ( $50 \mathrm{~m}$ apart) at $45 \mathrm{~m}$ a.s.l. were sampled in order to date the formation of the moraines. Although a number of Arran granite erratics are present on Kintyre, difficulties were encountered finding suitable samples with a correct (ice marginal landform) context in areas not affected by anthropogenic activity. No single landform with granite erratic boulders on top was identified; as a result samples in Glen Lussa were taken from three granite erratics resting on gently undulating ground, within a wider area of deglacial features, comprising meltwater channels, boulder spreads and low ridges. Since the samples do not specifically relate to any ice marginal landform, they were collected to provide a minimum age for the ground becoming free of glacier ice. Skyline topography was measured in the field at 15 degree increments at all of the sample locations to allow calculation of topographic shielding.

The samples were prepared at the University of Glasgow Cosmogenic Isotope Laboratory at the Scottish Universities Environmental Research Centre (SUERC). Beryllium was extracted from 
Quartz, which was separated and purified following modified procedures adopted from Kohl and Nishiizumi (1992). BeO targets were prepared for ${ }^{10} \mathrm{Be} /{ }^{9} \mathrm{Be}$ analysis using procedures modified from Child et al. (2000). Between 215 and $219 \mu \mathrm{g}$ Be was added as carrier and between 20 and $25 \mathrm{~g}$ of each sample was dissolved. The ${ }^{10} \mathrm{Be} /{ }^{9} \mathrm{Be}$ ratios were measured with the $5 \mathrm{MV}$ accelerator mass spectrometer at SUERC (Xu et al., 2010). ${ }^{10} \mathrm{Be} /{ }^{9} \mathrm{Be}$ ratios were normalised to NIST SRM 4325 with a ${ }^{10} \mathrm{Be} /{ }^{9} \mathrm{Be}$ ratio of $2.79 * 10^{-11}$ (in agreement with Nishiizumi et al., 2007). Process blanks prepared with the samples yielded an average ${ }^{10} \mathrm{Be} /{ }^{9} \mathrm{Be}$ ratio of $4.1 * 10^{-15}$. Blank-corrected ${ }^{10} \mathrm{Be} /{ }^{9} \mathrm{Be}$ ratios of the samples ranged from 53 to $114 * 10^{-15}$. Total one-sigma uncertainties for the concentrations determined at the SUERC-AMS Laboratory include the onesigma uncertainty of the AMS measurement and a $2 \%$ uncertainty as a realistic estimate for possible effects of the chemical sample preparation, which includes the uncertainty of the Be concentration of the carrier solution. Exposure ages were calculated using the CRONUS-Earth online calculator (Developmental version; Wrapper script 2.2, Main calculator 2.1, constants 2.2.1, muons 1.1; Balco et al., 2008) and calibrated using a locally derived ${ }^{10} \mathrm{Be}$ production rate based on ${ }^{10} \mathrm{Be}$ concentration in samples from erratic boulders on the terminal moraine of the Loch Lomond glacier advance (Fabel et al., 2012), approximately $75 \mathrm{~km}$ from the sites in this study. These sample ages are independently controlled by the radiocarbon ages of microfossils associated with a varve sequence deposited in a glacial lake at the time that the Loch Lomond moraine formed (Macleod et al., 2011). The calculated ${ }^{10} \mathrm{Be}$ concentrations from the moraine boulders resulted in a reference ${ }^{10} \mathrm{Be}$ production rate of $3.92 \pm 0.18$ atoms $\mathrm{g}^{-1} \mathrm{a}^{-1}$. The exposure ages reported here (Table 1) are based on the time-dependent Lm scaling scheme of the CRONUS-Earth online calculator (Lal, 1991; Stone, 2000), and assumption of a sampling surface erosion rate of $0 \mathrm{~mm} \mathrm{ka}{ }^{-1}$. For exposure ages $<20 \mathrm{ka}$, the other scaling schemes (the St, Du, De and Li schemes) available via the online calculator produce ages that differ on average from the Lm scheme by less than $1 \%$ of sample age. Similarly, for ages $<20 \mathrm{ka}$, assumption of an erosion rate of $1 \mathrm{~mm} \mathrm{ka}^{-1}$ increases our calculated exposure ages by $1.1 \%$.

\section{Geomorphology and sediments}

Glacial geomorphological features are synthesised in Figure 3. The details of individual assemblages are described below. 


\subsection{Subglacial assemblages}

\subsubsection{Tors}

Well developed granite tors are present on some of the highest summits on Arran, such as Caisteal Abhail (859 m a.s.l.), known as 'The Castles' (Fig. 4A), and Beinn Tarsuinn (826 m a.s.l.). These tors are high relief (up to $10 \mathrm{~m}$ ), and possess delicately balanced blocks and deep joint sets. Large granite tors elsewhere in Scotland have been shown to develop over long periods $\left(10^{5}-10^{6}\right.$ years $)$, requiring preservation during the glacial cycles of the middle and late Quaternary (Phillips et al., 2006). The tors on Arran exist in close proximity to major, north-south aligned, erosional breaches on the island (see below). Glacially transported 'perched' granite boulders also exist on several of the highest summits of Arran, demonstrating that these peaks were overwhelmed by ice during maximum stages of past glaciations (Ballantyne, 2007).

\subsubsection{Erosional basins and breaches}

Kintyre and Arran sit between three major north-south trending rock basins (Figs. 1,3). The Sound of Jura is a basin that reaches a depth of $200 \mathrm{~m}$ below present sea level, closely follows the strike of the underlying Dalradian metamorphic rocks, and is located over the position of the Ericht-Laidon Fault (B.G.S., 1985). The Kilbranan Sound is a basin between Kintyre and Arran that reaches a depth of $120 \mathrm{~m}$ below present sea level, and is located in a zone where Permian and Triassic sandstones have most likely been down-faulted into the harder underlying Dalradian rocks. The basin of the Northeast Arran Trough reaches a depth of $160 \mathrm{~m}$ below present sea level, and is positioned over down-faulted Permo-triassic sandstones, bounded by the Sound of Bute Fault and the Brodick Bay Fault. Kintyre is also dissected by one major east-west breach between Campbeltown and Macrihanish Bay. Here the Dalradian metamorphic rocks, which form the bedrock surface for much of the peninsula, are replaced by unconformably overlying and downfaulted Carboniferous and Devonian sedimentary rocks and lavas. The contrast in land surface elevation is particularly pronounced along the Kilchenzie Fault, which marks the boundary between the Dalradian and younger rocks. In each of these cases the deepening or breach is located over fault zones, often associated with an increase in fracture density and weathering depth, or softer rocks relative to the surrounding lithologies. A series of alpine-style glacial breaches also exist on the Isle of Arran, within the mountains of the Northern Granite Pluton (Fig 4B). These breaches are relatively clear of weathered rock, and possess ice-moulded bedrock surfaces with perched 
boulders. Tyrrell (1928) noted that the main 'through' valleys tend to have an approximate northsouth trend, which runs parallel to structural zones within the granite.

\subsubsection{Streamlined bedforms}

The streamlined bedforms observed on Kintyre and the south-western side of Arran comprise streamlined hills, crag-and tails, and drumlins. These bedforms can be grouped into individual flowsets based on their alignment, geographical distribution and relationship with topography (Fig. 3). Flow set statistics are shown in Table 2 .

Flow set 1 . Flow set 1 comprises west-north-westward aligned streamlined hills, crag and tails (Fig. 4C) and drumlins, which are present across the southern half of Kintyre. These bedforms maintain a similar alignment at all elevations on southern Kintyre, although they are absent on the far southern and south-eastern margins of the peninsula.

Flow set 2. Bedforms belonging to flow set 2 generally comprise west-south-westward aligned drumlins, streamlined hills and crag and tails, which are present over areas of thick till on the western central part of Kintyre. The eastward extent of these bedforms is marked by the transition from: (i) smooth, till-covered terrain on the western side of the central spine of the peninsula, to (ii) bedrock with little till cover in the east, where the north-south strike dominates morphology of the land surface. On the west coast of Kintyre, some of the flow set 2 bedforms are deeply incised by (sub)marginal meltwater channels (see below).

Flow set 3. Flow set 3 comprises west-south-westward aligned drumlins and crag-and-tails that occupy ground below $200 \mathrm{~m}$ a.s.l. around West Loch Tarbert. As observed for flow set 2, these bedforms are confined to the western dipping slopes to the west of the central spine of the peninsula. Their trend is slightly oblique to the dominant south-west strike of the underlying metasedimentary bedrock.

Flow set 4. Flow set 4 comprises two subsets of crag-and-tails and drumlins on the southern half of Kintyre that are diverted around the high ground in the south-west. Flow set 4a displays a westward pattern of convergence towards Macrihanish Bay, while flow set 4b displays a southwestward convergence around the Mull of Kintyre. 
Flow set 5 . Flow set 5 comprises, generally southward trending drumlins and crag-and-tails in south-western Arran, and sparse rock drumlins and crag-and-tails on eastern Kintyre and northwest Arran, which are locally oriented parallel to the metasedimentary bedrock strike. The drumlins and crag-and-tails on Arran show a weakly convergent pattern on the southern side of the island's southern hills.

\subsubsection{Subglacial sediments}

Thin, gravelly, shell-bearing tills have been identified locally on the eastern coast of Kintyre (Synge and Stephens, 1966). Thick deposits of subglacial diamicton, which exceed $20 \mathrm{~m}$ in places, are generally only present in the west. The margins of the western distribution of thick sediment is clearly represented by the appearance of bedrock structures which can be seen at the land surface across eastern parts of the peninsula (Fig 3). Sediment exposures in western Kintyre generally reveal a firm to very stiff, red to dark reddish brown, massive to fissile, matrix supported, silty clay diamicton, containing predominantly sub-angular, striated and faceted clasts (Fig. 5A). Clast content is dominated by metasedimentary lithologies, although some volcanic and rare granitic clasts are also present. Locally the diamicton contains lenses or pods of sorted sands. In general, the thick diamicton observed in western Kintyre possesses the characteristics of a subglacial traction till (Evans et al., 2006).

The three sites at Tangy Glen where shelly clays had been observed under till during the late 19th and early 20th Centuries were visited in 2010. At the time of field investigation, blue grey clays were exposed only at and below the water level of Tangy Burn. At Drumore Burn, $15 \mathrm{~m}$ of till was observed overlying 6-8 m of clast-supported, sub-rounded to sub-angular cobbles and gravels, with a sandy matrix (Fig. 5B). In places these moderately sorted gravels have a weakly developed herring-bone cross stratification. They are tentatively interpreted as beach gravels and overlie a clear platform cut into red Permian sandstone, which dips gently towards the coast. At this location, the platform surface lies at approximately $18 \mathrm{~m}$ a.s.l., only a few metres higher than the pre-last glacial cycle rock shore platform that was described by Gray $(1978,1993)$ at Glenacardoch Point to the north.

On Arran, Tyrrell (1928) noted that thick deposits of subglacial sediments are generally restricted to southern parts of the island, corresponding with the smooth, southward streamlined terrain observed on modern digital surface models (Fig. 3). The till in northern Arran is generally 
thinner, and sandier than in the south. At a number of the valley mouths, pale brown to grey, granite dominated till crosses geological boundaries, indicating radial transport from the central granite complex to the coastline - an observation also made by Gemmell (1973).

\subsection{Ice marginal assemblages}

\subsubsection{Meltwater channels}

A well-preserved set of north-east to south-west trending marginal or sub-marginal meltwater channels are present over an $8 \mathrm{~km}$ stretch of the western coastline of Kintyre (Fig. 6). Individual channels are continuous for at least $3 \mathrm{~km}$, their lower reaches having been erased by erosion of cliffs along the coastline. The channels are up to $150 \mathrm{~m}$ in width, and incise the surrounding till and the bedforms belonging to flowset 2 , by up to $20 \mathrm{~m}$. Isolated meltwater channels are present elsewhere on Kintyre, and Gemmell (1973) described a series of meltwater channels that descend along the western flanks Arran. In general, the meltwater channels on Kintyre and western Arran descend in an overall westward and southward direction.

\subsubsection{Perched delta}

A former delta, which is open to the North Channel, exists at an elevation of $130 \mathrm{~m}$ a.s.l at Innean Glen in south-west Kintyre (Fig. 7). It consists of $20 \mathrm{~m}$ of westward dipping, stratified sands and imbricated gravels and cobbles, which overlie a stiff, red, matrix supported, sandy clay diamicton. The diamicton contains isolated, striated and faceted, subangular clasts, and is interpreted as a subglacial till. At $130 \mathrm{~m}$ a.s.l., the delta surface lies far above any lateglacial or postglacial relative sea level high stand (Synge and Stephens, 1966). It must therefore relate to subaerial drainage ponding against a low-profile ice sheet margin that was grounded offshore, the local water depth being insufficient for floatation of ice that was at least $170 \mathrm{~m}$ thick (height of delta surface minus sea bed surface) at that time.

\subsubsection{Moraines}

Prominent moraines are rare on Kintyre. The 'thick morainic accumulations' described by Synge and Stephens (1966) near Kilchenzie, are interpreted here as drumlins and thick undulating till deposits, which have been deeply incised by meltwater channels (Fig.6). This reinterpretation is supported by exposures of stiff, subglacial traction till within these features. Some isolated moraines are, however, present on Kintyre. Subdued mounds with boulders scattered on their surfaces exist 
in Glen Lussa; they occur in association with westward descending meltwater channels. Three erratic boulders of Arran granite, having been transported at least $20 \mathrm{~km}$ across the Kilbrannan Sound, were selected from the Glen Lussa landform assemblage for cosmogenic nuclide analyses, to place a minimum constraint on the time since deglaciation.

Suites of moraines on Arran have been described by previous workers (Gemmell, 1973; Ballantyne, 2007). In the north of the island, a number of valleys and corries possess an inner suite of clear, boulder moraines (Fig. 8). These were previously interpreted by Gemmell (1973) as evidence for a late stillstand or readvance during the final stages of the Younger Dryas, and subsequently reinterpreted by Ballantyne (2007) as the maximum limits of glacier advance during the Younger Dryas, based on the mutually exclusive relationship with Lateglacial periglacial features. Both workers also recognised sets of more subdued outer moraines close to the coast at the valley mouths. Gemmell (1973) suggested that these outer moraines represented three separate stages during deglaciation (the innermost of the three he attributed to the Younger Dryas), while Ballantyne (2007) concluded that they pointed towards a pre-Younger Dryas (re)advance

A series of exposures reveal the stratigraphy in the vicinity of a set of 'outer' moraines at Dougarie, between $0.1 \mathrm{~km}$ and $0.7 \mathrm{~km}$ up the valley from where a prominent delta surface exists at 30-32 $\mathrm{m}$ a.s.l. (Fig. 9A). At the time of field investigation, four lithofacies were recognised in sections.

LFA 1 consists of stiff, thinly laminated, very pale brown, grey and white silts and clays, which show varying degrees of folding and attenuation (Figs. 9B,C). In places, the laminations are clearly graded. These silts and clays contain rare, isolated, sub-angular gravel- and cobblesized clasts. Sedimentary structures around the clasts include wrapped foliation and asymmetrical inclined folds indicative of an east to west sense of shear. Locally, the silts and clays are cut by sand-filled hydrofractures, which appear to have exploited detachments within the silts and clays. Small rafts of attenuated and folded silts and clays are contained within the sand. The base of LFA1 was not exposed. Where observed, the upper contact with LFA2 is erosional (Fig. 9D). LFA 1 is interpreted as a glacitectonite. It represents a period of proglacial deposition in a subaqeous environment, followed by phases of deformation associated with a local glacier advance from the east.

LFA 2 varies in thickness between 0 and $1.5 \mathrm{~m}$. It comprises a dense, grey to pale brown, gener- 
ally massive to locally stratified, matrix-supported diamicton, containing sub-angular clasts. The clasts are faceted and consist predominantly of granite (erratics) and metasedimentary lithologies. No primary bedding was observed in LFA 2. The upper contact with LFA 3 is gradational. LFA 2 is interpreted as a subglacial till, deposited by the overriding glacier

LFA 3 comprises a variably loose to dense, poorly sorted, clast-supported bouldery diamicton with coarse sandy matrix and infrequent lenses of sorted, bedded sands (Fig. 9E). LFA 3 is dominated by granite erratics, which are sourced from farther up the valley, and rare metasedimentary clasts. This lithofacies forms the topographic expression of the set of moraines, which vary in elevation from 25 - $40 \mathrm{~m}$ a.s.l. in the valley centre. These moraines were deposited during local glacier retreat, following its advance.

LFA 4 is sporadically present between moraines, and consists of loose, westward dipping, upward coarsening, stratified sands and gravels, which form delta foresets (Fig. 9F). LFA 4 probably represents deposition into ponds formed in proglacial depressions, during glacier retreat.

Collectively, these sediments support the views of both Gemmell (1973) and Ballantyne (2007), that glacier oscillations took place at the lower end of some valleys in Arran, during overall deglaciation. Many of the moraine (LFA 3) surfaces in the valley centre are lower than the surface elevation of the delta farther down the valley (Fig. 9A). Therefore their deposition during overall retreat is likely to have occurred after sea level had fallen from the highpoint marked by the delta surface at $32 \mathrm{~m}$ a.s.l. No clear surface boulders exist on the moraines where the sections were exposed. However, two boulders from low lateral moraine fragments, approximately $500 \mathrm{~m}$ farther up the valley, were sampled for cosmogenic nuclide analyses in an attempt to constrain the timing of moraine deposition.

\section{Chronology results}

Exposure ages for the sampled boulders in Glen Dougarie, Arran and Glen Lussa, Kintyre are shown in Table 1. The samples from Glen Dougarie on Arran yielded overlapping exposure ages with a mean of $16.23 \pm 0.969$ ka. The Dougarie ages pre-date, and are therefore consistent with, dated sediment accumulation in the outer Firth of Clyde (Peacock et al., 2012). They are only slightly older than the $16 \mathrm{ka}$ ice margin isochrone, which was placed just $20 \mathrm{~km}$ to the south by Clark et al. (2012), lending support to the framework ice sheet retreat chronology proposed 
by these authors. The ages also support previous suggestions by Gemmell (1973) and Ballantyne (2007) that these lowermost moraines on Arran pre-date the Younger Dryas.

Given their sampling context (discussed above), the Glen Lussa ages represent only a minimum period of time since deglaciation. This is confirmed since: (i) GL1 and GL2 are younger than calibrated radiocarbon ages and fauna assemblages obtained from sediment cores at the southern end of the Kilbranan Sound (Peacock et al., 2012); (ii) the ages are younger than those from Arran, contrary to the geomorphological evidence for the pattern of north-westward ice retreat (see below); and (iii) the ages are internally inconsistent, with the youngest sample (GL2, 13.0 \pm $0.8 \mathrm{ka}$ ) and oldest sample (GL3, $15.0 \pm 0.9 \mathrm{ka})$ not sharing overlapping uncertainties. Nonetheless the oldest sample, GL3, together with the Glen Dougarie samples, provide additional independent support to the contention by Peacock et al. (2012) that the outer Firth of Clyde was deglaciated before the opening of the Lateglacial Interstadial (Greenland Interstadial-1, $14.7 \mathrm{ka} \mathrm{BP}$ ).

\section{Ice sheet evolution over Kintyre and Arran}

The simplest interpretation of the growth and decay of the last BIIS over Kintyre and Arran, based on the geomorphological evidence reviewed above, is shown in Figure 10.

\subsection{Stage I: Southward ice sheet advance (Fig. 10A)}

Synge and Stephens (1966) interpreted the shell beds at Tangy Glen as glacial rafts and similar interpretations have been proposed for high-level shell beds and shelly tills elsewhere in Scotland (Merritt, 1992; Peacock and Merritt, 1997; Phillips and Merritt, 2008). If a rafting origin is correct, an advancing outlet glacier from the north is the most likely mechanism to have glacitectonically deposited the shelly clays on the eastern Kintyre coastline. A northern sourced advance is supported by the southerly transport of Glen Fyne granite erratics onto Arran (Tyrrell, 1928; Sissons, 1967), and by the north-south oriented over-deepened basins around Arran and Kintyre (Figs. 1,3). These geologically controlled, glacially carved fjords are too deep to have been cut during a single glacial cycle (Kessler et al., 2008), and the preservation of pre-MLD rock shore platforms and sediments at margin of the Sound of Jura are illustrative of an area where erosion during the last glacial cycle was limited. The over-deepened basins may therefore be considered products of 'average glacial conditions' through the Quaternary (Porter, 1989; Clapperton, 1997; Golledge et al., 2009). They determined the flow of the advancing, mostly land-based, MLD ice sheet before it expanded onto 
the Malin Shelf - a configuration that is replicated in numerical simulations of ice sheet flow during the build up phase (Hubbard et al., 2009).

\subsection{Stage II: non-topographically constrained west-north-westward ice flow onto the Malin Shelf} (Fig. 10B)

Bedforms belonging to flow set 1 were formed under west-north-westward directed ice movement. At that time ice flow was no longer topographically confined and warm-based ice movement occurred over southern Kintyre at all elevations (Table 2). West-north-westerly flow to the south of Arran, and across southern Kintyre is also supported by dispersal patterns of erratics from Ailsa Craig and Loch Doon, SW Scotland (Sissons, 1967). The pattern of ice flow could have transported shelly deposits from offshore to onshore over southern Arran (Watson, 1864). An ice sheet shear zone is inferred across southern Arran and central Kintyre separating southern warm-based ice that flowed towards the Malin Shelf, from northern cold-based, internally deforming ice. The cold-based ice to the north is suggested by: (i) the absence of west-north-westerly aligned bedforms over northern Arran and northern Kintyre; (ii) the preservation of delicate tors on some summits of northern Arran; and (iii) the absence of west-north-westward transported erratics of Arran granite on northern Kintyre (Horne et al., 1896; Eyles et al., 1949).

\subsection{Stage III: non-topographically constrained south-westward ice flow into the North Channel and} flow divergence over southern Kintyre (Fig. 10C)

Flow set 2 bedforms and some of the flow set 5 bedforms developed under warm-based ice moving towards the west-south-west and south-south-west, into the North Channel. West-southwestward ice motion occurred easily over the smooth terrain of western central Kintyre, where bedforms were developed in the thick traction till that must have protected the underlying pockets of shelly clays, beach gravels, and the rock platform. South-south-westward ice motion occurred over southern Arran, where bedforms are preserved on the present land surface. The absence of streamlined bedforms and the preservation of tors on northern Arran (Fig. 4A) suggests that it remained largely overlain by cold-based ice at that time. However, some localised warm-based ice flow through the north-south oriented glacial breaches, which possess ice-moulded rock surfaces, could have fed the south-south-westward directed ice movement. The high ground of southern Kintyre, where no south-westward oriented bedforms exist, may have been cold-based at that time. 
6.4. Stage IV: progressively topographically constrained south-westward ice flow and glacier retreat (Fig. 10D)

Bedforms belonging to flow sets 3, 4a and $4 \mathrm{~b}$, and 5 were forming under warm-based ice as glacier flow became topographically confined in the outer Firth of Clyde and Sound of Jura during deglaciation. The high ground of southern Kintyre deglaciated first, as indicated by the presence of the perched delta which fed into a lake that was ponded against a grounded glacier offshore (Fig. 7). On western Kintyre, ice marginal / sub marginal meltwater subsequently cut deep channels across thick deposits of traction till, dissecting some of the bedforms belonging to flow set 2 (Fig. 6). During this phase of events ice flow in the outer Firth of Clyde was directed through the fault-controlled gap between Campbeltown and Machrihanish Bay, demonstrated by the convergent pattern of flow set $4 \mathrm{a}$, which generally occurs at a lower elevation than, and is partially superimposed on, flow set 1 . Southward-flowing ice in the Firth of Clyde was diverted around the high ground of northern Arran, although some basal ice motion may have taken place through the southward oriented valleys and glacial breaches transporting sub-rounded granite boulders to the south and south-west. The spreads of sand and gravel offshore around Kintyre (Fig 3) probably accumulated as ice-proximal subaqeous fans during this overall phase of events.

\subsection{Stage V: fjord glacier retreat and oscillations of Arran icefield (Fig. 10E)}

The distribution and orientation of ice marginal meltwater channels shows that the major pathways of glacier retreat was along corridors of low lying ground, and principally through the over-deepened, fault controlled, glacially carved basins of the Kilbrannan Sound and North East Arran Trough. The pattern of deglaciation suggested here supports that deduced earlier by Gemmell (1973). Rapid glacier retreat in the main basins would have been aided by calving as the ice margins thinned and pulled back into deeper water. The sediments and geomorphology at Dougarie, on western Arran, indicate that an advance of a locally sourced glacier took place following separation from the main outlet glacier in the Kilbrannan Sound. Retreat from this local advance took place $\sim 16.2 \mathrm{ka}$, and probably post-dated a fall in relative sea level from the highstand that produced the main delta at $32 \mathrm{~m}$ (Fig. 9A) and other high lateglacial shorelines that are only present on the southern half of the island (Gemmell, 1973). This timing supports relative sea level simulations for the area, where a falling relative sea level is modelled between $\sim 16.5$ and $\sim 15$ ka BP (Shennan et al., 2006). Glaciers are inferred to have advanced or oscillated at 
similar positions in other valleys on Arran at that time (Gemmell, 1973; Ballantyne, 2007). This may reflect internal adjustments of the Arran ice field as it responded to either: (i) the retreat of larger confining glaciers in the surrounding Kilbrannan Sound and North-east Arran Trough, or (ii) enhanced snowfall over the high ground of northern Arran, following the deglaciation of offshore areas farther to the west. The overall configuration proposed at this stage is very similar to that envisaged by Gemmell (1973). The general timing proposed here is broadly similar to the timing of retreat proposed by Clark et al. (2012), and supports simulations of large marine-based ice losses in the North Channel region and outer Firth of Clyde between 17 ka and 16 ka BP (Hubbard et al., 2009).

\subsection{Stage VI: Advance of Arran glaciers during the Younger Dryas (Fig. 10F)}

The suites of clearly defined, sharp-crested moraines that exist in the upper reaches of the valleys of northern Arran (Figs 3,8) point towards an episode of alpine glaciation when small corrie glaciers grew. These moraines have been recognised by several previous authors (e.g. Tyrrell, 1928; Gemmell, 1973; Ballantyne, 2007). Detailed mapping of the moraine limits and their mutually exclusive relationship with periglacial features led Ballantyne (2007) to conclude that this last phase of glaciation took place during the Younger Dryas (12.9-11.5 ka BP). This view is supported by the observations made during this study.

\section{Regional ice sheet evolution}

Combining our reconstructed sequence of events with recently published interpretations from south-west Scotland (Salt and Evans, 2004), west-central Scotland (Finlayson et al., 2010), northern England (Livingstone et al., 2012), north-east Ireland (Greenwood and Clark, 2009; McCabe and Williams, 2012), and the Malin Shelf (Dunlop et al., 2010) allows us to attempt to synthesise the overall growth and decay of the western zone (Clyde-North Channel-Malin Shelf) of the last BIIS (Figs. 11 A-G, 12).

Published dates from interstadial deposits that underlie till indicate that ice advance into the Clyde and Ayrshire basins occurred after 35 ka BP (Bos et al., 2004; Brown et al., 2007; Jacobi et al., 2009). Prior to that, a more restricted ice cap, which intermittently terminated at the marine limit, existed over the western Scottish Highlands from $\sim 45$ ka BP (Knutz et al., 2001; Scourse et al., 2009). The advancing outlet lobes of the ice cap encountered reverse slopes in 
the Clyde and Ayrshire basins, and in the north-east Arran Trough, the Kilbrannan Sound, and Sound of Jura (Figs 10A, 11A). These topographic settings, combined with the presence of water at the ice margins provided favourable conditions for glacitectonic deformation (Aber et al., 1989), and glacitectonic structures have been recognised in sediments in the Clyde basin (McMillan and Browne, 1983; Browne and McMillan, 1989).

The Western Highlands ice cap joined with a smaller ice cap centred over the Southern Uplands, prior to a major expansion of the BIIS, which occurred after 29 ka BP (Scourse et al., 2009). This phase was marked by the western advance (average rate of $\sim 30 \mathrm{~m} \mathrm{a}^{-1}$ ) of marine-based ice sheet sectors over the Malin Shelf (Dunlop et al., 2010), and elsewhere on the western British-Irish continental shelf (Clark et al., 2012; O'Cofaigh et al., 2012; Everest et al., 2013; Howe et al., 2012). An ice divide had developed over Arran, most of Kintyre, and the adjacent marine areas at that time, acting as a link to the ice dome over the western Highlands (Fig. 11B). Eastward ice flow occurred over west central Scotland (Finlayson et al., 2010), and through topographic corridors in northern England (Livingstone et al., 2012). Slow moving ice in the vicinity of the ice divide did not significantly modify the landscape of Kintyre and Arran. An ice ridge had also developed over the North Channel, bridging the British and Irish ice centres (Greenwood and Clark, 2009).

The ice divide that was positioned over Arran and Kintyre migrated $\sim 60 \mathrm{~km}$ to the east during a phase, or phases, of enhanced drawdown to the western marine margins of the ice sheet, drained by the large Barra-Donegal Fan / Hebrides Ice Stream (Dunlop et al., 2010; O'Cofaigh et al., 2012; Howe et al., 2012) (Figs. 10B, 11C). This was associated with the development of west-north-west oriented streamlined bedforms at all elevations over southern Kintyre, and possibly also transport of shelly till onto southern Arran (Fig 10, stage II). Ice flowing over southern Arran and Kintyre merged with powerful north-westerly flowing ice which overwhelmed the topography of Islay (Cousins, 2012). However, delicate landforms on northern Arran were preserved beneath a cold-based ice sheet sticky spot, which existed within an overall area of accelerating ice flow. Recent analysis of geochronological data from the Irish Sea Basin show that the retreat of the Irish Sea Ice Stream slowed between $\sim 23$ and $\sim 20$ ka BP, as the margin entered the constriction between Ireland and Wales (Chiverrell et al., 2013). Slowing of the Irish Sea Ice Stream, combined with drawdown to the Barra-Donegal Fan / Hebrides Ice Stream could have driven the North Channel ice divide to the south-east over the northern Irish Sea. Such a migration is captured in both 
the geomorphological reconstruction by (Greenwood and Clark, 2009) and numerical simulations by (Hubbard et al., 2009). Peaks in IRD concentrations observed in core MD95-2006, from the Barra Fan, suggest that distinct pulses of iceberg discharge took place, from $\sim 27$ ka BP (Fig. 11). These pulses may relate to earlier ice stream drawdown and ice berg discharge events, possibly documenting interplay of the Barra-Donegal Fan / Hebrides Ice Stream and the Irish Sea Ice Stream as the BIIS altered between configurations approximating those presented in Figures 11B and $11 \mathrm{C}$.

A significant iceberg discharge event at the Barra Fan, which may have been associated with large ice losses over the Malin Shelf, ceased $\sim 18.5$ ka BP (Fig. 11) (Knutz et al., 2001). Following this, the BIIS is suggested to have thickened again over north-east Ireland, advancing at its margins during the Killard Point Stadial, at or soon after 17 ka BP (McCabe et al., 1998; McCabe, 2008)(Fig. 11D). Livingstone et al. (2012) summarised the evidence for a readvance of Scottish-sourced ice into northern England at a similar time, although they note that chronological constraints are insufficient to conclusively link the two events. The ice sheet may also have thickened over Arran, most of Kintyre, and the North Channel at this stage, under which little landscape modification took place (Fig 11D), although some south-westward ice flow may have begun to occur over westernmost parts of Kintyre.

McCabe and Williams (2012) provided strong evidence for a later advance of Scottish-sourced ice onto the East Antrim coast of Northern Ireland (the East Antrim Coastal Readvance). We suggest that the East Antrim Coastal Readvance was caused by the delayed response of Scottishsourced ice to warming at the end of the Killard Point Stadial (17-16.5 ka BP)(Fig. 12). The Irish Ice Sheet is reconstructed to have been only 500 m thick during the Killard Point Stadial, and therefore extremely sensitive to any rise in equilibrium line altitude (Clark et al., 2009), while the Scottish sector was larger and thicker, with its core positioned over the western Scottish Highlands (Fig. 12A). In addition, initial ice sheet break up over the Malin Shelf and the opening of a marine embayment may have allowed more precipitation to reach Scottish source areas, as suggested by McCabe and Williams (2012). As a result, rapid wasting of the Irish Ice Sheet meant that it no longer obstructed Scottish-sourced ice. The North Channel ice divide collapsed and the Scottish Ice Sheet margin was allowed to temporarily advance over the East Antrim coast (Figs. 10C, 11E, 12B), before it too rapidly retreated across reverse slopes, reaching the inner Firth of Clyde in $\sim$ 
500 years or less - requiring retreat rates in the order of $10^{2} \mathrm{ma}^{-1}$ (Figs. 10D, E and 11F, G). Minor readvances or stillstands occurred during that time, possibly as local outlet glaciers responded to the retreat of larger confining ice masses, or as the wasting ice sheet allowed precipitation to be focused elsewhere. We suggest that this overall phase of rapid thinning and retreat of the Scottish Ice Sheet (south-west sector) may be associated with a peak in iceberg calving, identified in the Barra Fan IRD record at 16 ka BP (Knutz et al., 2001) (Fig. 11).

Our scenario differs somewhat to the proposal by McCabe and Williams (2012) that the East Antrim Coastal Readvance was part of a larger 'North Channel Readvance' approximately 1515.5 ka BP, with contemporary ice margins across the East Antrim Plateau $(\sim 300 \mathrm{~m})$, at the Kilmarnock moraine (100 m a.s.l.) in the Ayshire basin (Finlayson et al., 2010) and Blantyreferme moraine (50 m a.s.l.) in the Clyde basin (Browne and McMillan, 1989) (Fig. 1). We find it difficult to support the overall configuration and timing of the 'North Channel Readvance', proposed by McCabe and Williams (2012) for two reasons. First, linking the East Antrim Coastal Readvance with glacier limits in the Ayrshire and Clyde basins would require ice surface slopes along eastward flow lines to be $\sim 5$ times steeper that those flowing onto the north-east Irish coastline. The unusual ice surface topography would necessitate much higher basal shear stresses along eastern flow lines, which is difficult to reconcile with the soft sediment (marine) bed in the outer Firth of Clyde, and the presence of streamlined eastward directed bedforms (mean elongation ratio: 4.3) in Ayrshire (Finlayson et al., 2010). Furthermore, the thickness of ice required to over top the Antrim Plateau (300 m a.s.l.) means that it would have been grounded in the North Channel at the time of the advance, ruling out the existence of a very low gradient ice shelf as a potential solution to the reconstruction by McCabe and Williams (2012). Second, McCabe and Williams' proposed timing of 15-15.5 ka BP is within error of radiocarbon ages from molluscs in sediment cores, suggesting that glaciomarine conditions existed around Islay and in the outer Firth of Clyde at that time (Peacock et al., 2012). The exposure ages from moraines at Dougarie on Arran, also suggest that the Kilbrannan Sound and outer Firth of Clyde were ice free by $\sim 16.2 \mathrm{ka}$ BP, and therefore that the East Antrim Coastal Readvance must have occurred slightly earlier than this. The scenario presented here also differs from part of the reconstruction of Finlayson et al. (2010) (their Fig. 17B), who considered ice marginal oscillations in East Antrim and the outer Firth of Clyde (though not necessarily contemporaneous) to be of the same overall phase of events at the GS-2 to GI-1 
transition. These events were probably earlier, with the ice sheet having retreated from much of the outer Firth of Clyde by $\sim 16$ ka BP, supporting the more recent reconstruction of Clark et al. $(2012)$.

\section{Ice sheet evolution and the glacial landscape}

Our results and reconstruction based on the geomorphological record concurs with the prevailing view of a dynamic former BIIS (e.g. Bradwell et al., 2008; Greenwood and Clark, 2009; Livingstone et al., 2012). The ice sheet expanded from a mountain ice cap with tidewater margins, to the continental shelf edge in $\sim 7$ ka or less. The addition of the marine sector to the ice sheet was accompanied by a marked change in ice-flow directions in the vicinity of Arran and Kintyre. Initially, ice flow had been directed through the geologically influenced north-south oriented fjord basins. These over-deepened glacial troughs probably represent a position that was often reached by restricted, marine-proximal mountain ice sheets during the middle and late Quaternary. Ice flow along these corridors was then abandoned once the extensive Malin Shelf sector became established, with powerful ice sheet drawdown towards the continental shelf forcing ice to flow at right angles to the initial flow direction.

The marine terminating phase of ice sheet glaciation was strongly influenced by episodes of ice divide migration, possibly linked to ice streaming and large calving events. Importantly, however, stable ice sheet configurations were also a feature of the marine-influenced phase. For example, while the main west-east ice divide migrated by up to $60 \mathrm{~km}$ over low relief areas in the outer Firth of Clyde and Clyde and Ayrshire basins, it remained a relatively stable, stationary feature over the western Scottish Highlands. Similarly, the zone of cold based ice (ice sheet sticky spot?) over northern Arran was probably a permanent and stationary feature through the whole marine phase of the ice sheet cycle. These stable features in the BIIS provide some support to recent suggestions of long term stability (over $10^{4}$ years or more), influenced by subglacial topography, for parts of the West Antarctic Ice Sheet (Ross et al., 2011).

The North Channel ice divide linked an ice ridge over the Southern Uplands in Scotland with the higher ground of north-east Ireland. Although it migrated over time due to the interplay between the Barra-Donegal Fan / Hebrides Sea Ice Stream and the Irish Sea Ice Stream, it remained a constant feature of the marine BIIS until the Irish Ice Sheet rapidly decayed on land, after 17 ka 
BP (Fig 12). Collapse of the North Channel ice divide allowed the Scottish Ice Sheet to temporarily advance over north-east Ireland, before it too retreated back into the coastal fjords, at rates in the order of $10^{2} \mathrm{~m} \mathrm{a}^{-1}$, and readopted the restricted north-south, fjord-aligned ice flow pattern. This represents a relatively rapid phase of ice sheet decay, exceeding the overall average retreat rate from the shelf edge, which was in the order of $10^{1} \mathrm{~m} \mathrm{a}^{-1}$, similar to the rates identified by Clark et al. (2012).

The landscape of Kintyre and Arran lay under both a small land-based ice sheet with tidewater margins and larger ice sheet with significant marine sectors. These different ice sheet configurations and the variability in conditions at the ice sheet bed are highlighted by the composite landscape that is now preserved; it includes: (i) tors of probable middle Quaternary age; (ii) breaches and rock basins that are hundreds of metres in depth; (iii) an (interglacial?) rock shore platform, which was cut prior to the last glacial cycle; (iv) preserved pre-Late Devensian marine sediments, which may have been emplaced by glacitectonic rafting at the start of the last glacial cycle; (v) streamlined bedrock and soft sediment bedforms that were developed during the maximum phases, and subsequent retreat phases of the last BIIS; and (vi) ice marginal assemblages formed during a readvance of alpine-style glaciers during the Younger Dryas.

The first order components of the glacial landscape are the deep, geologically controlled, northsouth aligned rock basins, used by Clayton (1974) in his 'relatively high glacial erosion' (Zone III) classification of the landscape. We have demonstrated that these features do not relate to the most recent period of extensive marine-terminating ice sheet glaciation. The scales $\left(10^{2} \mathrm{~m}\right.$ vertical, and $10^{3}-10^{4} \mathrm{~m}$ horizontal) of the rock basins indicate that they have been cut over repeated glacial cycles (Kessler et al., 2008). The rock basins extend $\sim 50-100 \mathrm{~km}$ from lines of maximum glacial erosion modelled in the Scottish Younger Dryas ice cap by Golledge et al. (2009) suggesting western Scotland has often supported a mountain ice sheet with tidewater margins, slightly larger than the Younger Dryas ice configuration. This 'restricted, mountain ice sheet with tidewater outlets' configuration is suggested to have been the dominant glacial mode in Britain for large parts of the Quaternary, and particularly prior to 1.1 Ma BP (Lee et al., 2012). Similar patterns in the Quaternary glacial landscape have been recognised in Fennoscandia, where parts of the landscape were shaped exclusively during restricted mountain ice sheet phases, which dominated the early and middle Quaternary (Fredin, 2002; Kleman et al., 2008). These findings have implications for 
studies on present ice sheets, where modern geophysical techniques are now being used to map the glacial landscape under the ice (e.g. Smith et al., 2007; King et al., 2009). At the margins of the Ellsworth Subglacial Highlands, for example, erosional basins at $10^{2}-10^{3}$ vertical and $10^{4}$ horizontal scales have been suggested to have formed under an early marine-proximal, mountain ice sheet, and do not relate to flow of the present marine WAIS (Ross et al., 2013). These suggestions are supported by our reconstruction of the BIIS and its relationship with the glacial landscape of western Scotland.

\section{Conclusions}

The following conclusions can be drawn by synthesising the new findings from Arran and Kintyre with published work from the wider area.

- The glacial landscapes of the Kintyre peninsula and the island of Arran preserve a record of both restricted, marine-proximal mountain glaciation and shelf-edge glaciation. The diverse, composite landscape has enabled the evolution of the western marine margin of the last BIIS to be reconstructed.

- Ice advance was initially directed through north-south aligned, geologically-controlled basins that have been carved during successive glacial cycles. These basins record a restricted, marine-proximal mountain ice sheet configuration, slightly larger than the Younger Dryas glacial extent, which probably existed for large parts of the middle and late Quaternary.

- Published dates indicate that ice advanced to the shelf edge after $\sim 35 \mathrm{ka} \mathrm{BP}$, at an average rate of $\sim 30 \mathrm{~m} \mathrm{a}^{-1}$. The development of a marine sector was marked by a $90^{\circ}$ shift in ice flow direction over Arran, Kintyre and the adjacent marine areas. The marine phase of the western BIIS margin saw ice divide migration by up to $60 \mathrm{~km}$, possibly linked to ice streaming and calving events. However, stable ice sheet features also persisted over subglacial topographic highs.

- A significant calving event at the western margin of the BIIS was followed by ice sheet regrowth during the Killard Point Stadial (KPS). The KPS ended $\sim 16.5$ ka BP with rapid wasting of the Irish Ice Sheet on land. The North Channel ice divide collapsed as a result, al- 
lowing grounded Scottish ice to advance over north-eastern Ireland (the East Antrim Coastal Readvance).

- Subsequent retreat of Scottish ice to the inner fjords was rapid, in the order of $10^{2} \mathrm{~m} \mathrm{a}^{-1}$. Overall ice retreat was accompanied by oscillations of the Arran ice field, possibly due to removal of confining fjord glaciers, or refocusing of precipitation.

- The 'restricted' and 'extensive' ice sheets had very different flow regimes over Arran, Kintyre and the surrounding area. First order features in the glacial landscape relate to the former. Similar first order features, relating to restricted glacial conditions, may be identified in geophysical surveys used to map subglacial highland landscapes under interior parts of modern ice sheets.

\section{Acknowledgements}

Jon Merritt, Dayton Dove, Emrys Philips, Diarmad Campbell, and Mike McCormack are thanked for discussions of aspects of this work. The journal reviewers, Paul Dunlop and Henry Patton, are thanked for their constructive comments which improved the paper. This work was supported by the British Geological Survey's (BGS) Geology and Landscape Scotland programme and by BGS training. Published with the permission of the Executive Director of BGS (NERC). 


\section{References}

Aber, J.S., Croot, D.G., Fenton, M.M., 1989. Glaciootectonic landforms and structures. Kluwer Academic Publishers, Dordrecht.

Balco, G., Stone, J., Lifton, N., Dunai, T., 2008. A complete and easily accessible means of calculating surface exposure ages or erosion rates from 10Be and 26Al measurements. Quaternary Geochronology 3, 174-195.

Ballantyne, C.K., 2007. The Loch Lomond Readvance on north Arran: glacier reconstruction and palaeoclimatic implications. Journal of Quaternary Science 22, 343-359.

B.G.S., 1985. Clyde. 1:25,000 Series: Sea bed sediments and Quaternary geology. British Geological Survey, Keyworth, Nottingham.

Bos, J.A.A., Dickson, J.H., Coope, G.R., Jardine, W.G., 2004. Flora, fauna and climate of Scotland during the Weichselian Middle Pleniglacial - palynological, macrofossil and coleopteran investigations. Palaeogeography, Palaeoclimatology, Palaeoecology 204, 65 - 100.

Boulton, G.S., Clark, C.D., 1990. A highly mobile laurentide ice sheet revealed by satellite images of glacial lineations. Nature 346, 813-817.

Bradwell, T., Stoker, M.S., Golledge, N.R., Wilson, C.K., Merritt, J.W., Long, D., Everest, J.D., Hestvik, O.B., Stevenson, A.G., Hubbard, A.L., Finlayson, A.G., Mathers, H.E., 2008. The northern sector of the last British Ice Sheet: Maximum extent and demise. Earth-Science Reviews 88, $207-226$.

Brown, E.J., Rose, J., Coope, R.G., Lowe, J.J., 2007. An MIS 3 age organic deposit from Balglass Burn, central Scotland: palaeoenvironmental significance and implications for the timing of the onset of the LGM ice sheet in the vicinity of the British Isles. Journal of Quaternary Science 22, 295-308.

Browne, M., McMillan, A., 1989. Quaternary Geology of the Clyde Valley. Technical Report. British Geological Survey. Keyworth, Nottingham.

Bryce, J., 1865. On the order of succession in the drift-beds of the island of Arran. Quarterly Journal of the Geological Society of London 21, 204-213.

Child, D., Elliot, G., Mifsud, C., Smith, A., Fink, D., 2000. Sample processing for earth science studies at ANTARES. Nuclear Instruments and Methods in Physics Research B 172, 856-860.

Chiverrell, R.C., Thrasher, I.M., Thomas, G.S.P., Lang, A., Scourse, J.D., Van Landeghem, K.J.J., McCarroll, D., Clark, C.D., O'Cofiagh, C., Evans, D.J.A., Ballantyne, C.K., 2013. Bayesian modelling the retreat of the irish sea ice stream. Journal of Quaternary Science 28, 200-209.

Chmeleff, J., von Blanckenburg, F., Kossert, K., Jakob, D., 2010. Determination of the 10Be half-life by multicollector ICP-MS and liquid scintillation counting. Nuclear Instruments and Methods in Physics Research Section B: Beam Interactions with Materials and Atoms 268, $192-199$.

Clapperton, C.M., 1997. Greenland ice cores and North Atlantic sediments: implications for the last glaciation in Scotland, in: Gordon, J. (Ed.), Reflections on the Ice Age in Scotland. The Scottish Association of Geography Teachers and Scottish natural Heritage, Glasgow.

Clark, C.D., Evans, D.J.A., Khatwa, A., Bradwell, T., Jordan, C.J., Marsh, S.H., Mitchell, W.A., Bateman, M.D., 2004. Map and GIS database of glacial landforms and features related to the last British Ice Sheet. Boreas 33 , 
359-375.

Clark, C.D., Hughes, A.L., Greenwood, S.L., Jordan, C., Sejrup, H.P., 2012. Pattern and timing of retreat of the last British-Irish Ice Sheet. Quaternary Science Reviews 44, 112-146.

Clark, J., McCabe, A.M., Schnabel, C., Clark, P.U., McCarron, S., Freeman, S.P.H.T., Maden, C., Xu, S., 2009. Cosmogenic 10Be chronology of the last deglaciation of western Ireland, and implications for sensitivity of the Irish Ice Sheet to climate change. Geological Society of America Bulletin 121, 3-16.

Clayton, K.M., 1974. Zone of glacial erosion. Institute of British Geographers Special Publication 7, $163-176$.

Conway, H., Catania, G., Raymond, C., Gades, A., Scambos, T., Engelhardt, H., 2002. Switch of flow in an Antarctic ice stream. Nature 419, 465-467.

Cousins, R., 2012. The glaciation history of Islay: implications for ice sheet dynamics in south-west Scotland. Unpublished BSc thesis. University of Edinburgh.

Dunlop, P., Shannon, R., McCabe, M., Quinn, R., Doyle, E., 2010. Marine geophysical evidence for ice sheet extension and recession on the Malin Shelf: New evidence for the western limits of the British Irish Ice sheet. Marine Geology 276, $86-99$.

Evans, D.J.A., Phillips, E.R., Hiemstra, J.F., Auton, C.A., 2006. Subglacial till: Formation, sedimentary characteristics and classification. Earth-Science Reviews 78, 115 - 176.

Everest, J.D., Bradwell, T., Stoker, M., Dewey, S., 2013. New age constraints for the maximum extent of the last British-Irish Ice Sheet (NW sector). Journal of Quaternary Science 28, 2-7.

Eyles, V.A., Simpson, J.B., MacGregor, A.G., 1949. The Geology of Central Ayrshire. Memior of the Geological Survey of Scotland, HMSO, Edinburgh.

Fabel, D., Ballantyne, C.K., Xu, S., 2012. Trimlines, blockfields, mountain-top erratics and the vertical dimensions of the last British-Irish Ice Sheet in NW Scotland. Quaternary Science Reviews 55, 91-102.

Finlayson, A., Merritt, J., Browne, M., Merritt, J., McMillan, A., Whitebread, K., 2010. Ice sheet advance, dynamics, and decay configurations: evidence from west central Scotland. Quaternary Science Reviews 29, 969-988.

Fredin, O., 2002. Glacial inception and Quaternary mountain glaciations in Fennoscandian. Quaternary International 95-96, 99-112.

Gemmell, A.G., 1973. The deglaciation of the Isle of Arran, Scotland. Transactions of the Institute of British Geographers 59, 25-39.

Geological Survey of Scotland, 1913. Argyllshire Sheet 246. Geological Survey of Scotland, Edinburgh.

Golledge, N., Hubbard, A., Sugden, D.E., 2009. Mass balance, flow, and subglacial processes of a modelled Younger Dryas ice cap in Scotland. Journal of Glaciology 55, 32-42.

Graham, A.G.C., Lonergan, L., Stoker, M.S., 2009. Seafloor glacial features reveal the extent and decay of the last British Ice Sheet, east of Scotland. Journal of Quaternary Science 24, 117-138.

Gray, J.M., 1978. Low-level shore platforms in the south-west Scottish Highlands: altitude, age and correlation. Transactions of the Institute of British Geographers N.S3, 151-164.

Gray, J.M., 1993. Glenacardoch Point, in: Gordon, J.E., Sutherland, D.G. (Eds.), Quaternary of Scotland. Chapman and Hall, London.

Greenwood, S., Clark, C.D., 2009. Reconstructing the last Irish Ice Sheet 2: a geomorphologically-driven model of 
ice sheet growth, retreat and dynamics. Quaternary Science Reviews 28, 3101-3123.

Gregory, J.W., 1926. The moraines, boulder clay and glacial sequence of south-western Scotland. Transactions of the Geological Society of Glasgow 17, 354-376.

Hall, A.M., Sugden, D.E., 1987. Limited modification of mid-latitude landscapes by ice sheets: The case of northeast Scotland. Earth Surface Processes and Landforms 12

Horne, J., Robertson, D., Jamieson, T., Fraser, J., Kendall, P., Bell, D., 1896. The character of the high-level shell-bearing deposits in Kintyre. Report of the British Association for the Advancement of Science for 1896 , $378-399$

Howe, J.A., Dove, D., Bradwell, T., Gafeira, J., 2012. Submarine geomorphology and glacial history of the sea of the hebrides, UK. Marine Geology 315-318, $64-76$

Hubbard, A., Bradwell, T., Golledge, N., Hall, A., Patton, H., Sugden, D., Cooper, R., Stoker, M., 2009. Dynamic cycles, ice streams and their impact on the extent, chronology and deglaciation of the British-Irish ice sheet. Quaternary Science Reviews 28, $758-776$.

Hughes, A.L.C., Greenwood, S.L., Clark, C.D., 2011. Dating constraints on the last British-Irish Ice Sheet. Journal of Maps 2010, 156-183.

Jacobi, R.M., Rose, J., MacLeod, A., Higham, T.F.G., 2009. Revised radiocarbon ages on wooly rhinoceros (Coelodonta antiquitatis) from western Scotland: significance for the timing of extinction of wooly rhinoceros in Britain and the onset of the LGM in central Scotland. Quaternary Science Reviews 28, 2551-2556.

Kessler, M.A., Anderson, R.S., Briner, J.P., 2008. Fjord insertion into continental margins driven by topographic steering of ice. Nature Geoscience 1, $365-369$.

King, E.C., Hindmarsh, R.C.A., Stokes, C.R., 2009. Formation of mega-scale glacial lineations observed beneath a West Antarctic ice stream. Nature Geoscience 2, 585 - 588.

Kleman, J., Borgstrőm, I., 1996. Reconstruction of palaeo-ice sheets: The use of geomorphological data. Earth Surface Processes and Landforms 21, 893-909.

Kleman, J., Glasser, N.F., 2007. The subglacial thermal organisation (STO) of ice sheets. Quaternary Science Reviews 26, $585-597$

Kleman, J., Hättestrand, C., Borgstrőm, I., Stoeven, A., 1997. Fennoscandian palaeoglaciology reconstructed using a glacial geological inversion model. Journal of Glaciology 43, 283-299.

Kleman, J., Jansson, K., Angelis, H.D., Stroeven, A.P., Hättestrand, C., Alm, G., Glasser, N., 2010. North American Ice Sheet build-up during the last glacial cycle, 115-21kyr. Quaternary Science Reviews 29,2036 - 2051.

Kleman, J., Stroeven, A.P., Lundqvist, J., 2008. Patterns of Quaternary ice sheet erosion and deposition in Fennoscandia and a theoretical framework for explanation. Geomorphology 97, 73 - 90.

Knutz, P.C., Austin, W.E., Jones, E.J.W., 2001. Millenial-scale depositional cycles related to British Ice Sheet variability and North Atlantic paleocirculation since 45 kyr B.P., Barra Fan, U.K. margin. Paleoceanography 16, $53-64$.

Kohl, C., Nishiizumi, K., 1992. Chemical isolation of quartz for measurement of in situ-produced cosmogenic nuclides. Geochimica et Cosmochimica Acta 56, 3586-3587.

Korschinek, G., Bergmaier, A., Faestermann, T., Gerstmann, U., Knie, K., Rugel, G., Wallner, A., Dillmann, I., 
Dollinger, G., von Gostomski, C.L., Kossert, K., Maiti, M., Poutivtsev, M., Remmert, A., 2010. A new value for the half-life of $10 \mathrm{Be}$ by heavy-ion elastic recoil detection and liquid scintillation counting. Nuclear Instruments and Methods in Physics Research Section B: Beam Interactions with Materials and Atoms 268,187 - 191.

Lal, D., 1991. Cosmic ray labeling of erosion surfaces: in situ nuclide production rates and erosion models. Earth and Planetary Science Letters 104, 424-439.

Lee, J., Busschers, F.S., Sejrup, H.P., 2012. Pre-Weichselian Quaternary glaciations of the British Isles, The Netherlands, Norway and adjacent marine areas south of 68 degrees North: implications for long-term ice sheet development in northern Europe. Quaternary Science Reviews 44, 213-228.

Livingstone, S.J., Evans, D.J.A., O’Cofaigh, C., Davies, B.J., Merritt, J.W., Huddart, D., Mitchell, W.A., Roberts, D.H., Yorke, L., 2012. Glaciodynamics of the central sector of the last British-Irish Ice Sheet in Northern England. Earth-Science Reviews 111, 25 - 55.

Livingstone, S.J., O’Cofaigh, C., Evans, D.J.A., 2009. A major ice drainage pathway of the last British-Irish Ice Sheet: the Tyne Gap, northern England. Journal of Quaternary Science 25, 354-370.

Lowe, J.J., Rasmussen, S.O., Bjőrck, S., Hoek, W., Steffensen, J., Walker, M.J.C., Yu, Z., the INTIMATE group, 2008. Synchronisation of palaeoenvironmental events in the North Atlantic region during the Last Termination: a revised protocol recommended by the INTIMATE group. Quaternary Science Reviews 27, 6-17.

Macleod, A., Palmer, A.P., Lowe, J.J., Rose, J., Bryant, C., Merritt, J., 2011. Timing of glacier response to Younger Dryas cooling in Scotland. Global and Planetary Change 79, 264-274.

Maddox, S.J., Blow, R.A., O'Brien, S.R., 1993. The geology and the hydrocarbon prospectivity of the North Channel Basin, in: Meadows, N., Trueblood, S., Hardman, M., Cowan, G. (Eds.), Petroleum geology of the Irish Sea and adjacent areas, Geological Society Special Publication No. 124. The Geological Society, London.

McCabe, A.M., 2008. Glacial Geology and Geomorphology: the Landscapes of Ireland. Dunedin Academic Press, Edinburgh.

McCabe, A.M., Knight, J., McCarron, S.G., 1998. Evidence for Heinrich Event 1 in the British Isles. Journal of Quaternay Science 13, 847-855.

McCabe, A.M., Williams, G.D., 2012. Timing of the East Antrim Coastal Readvance: phase relationships between lowland Irish and upland Scottish ice sheets during the Last Glacial Termination. Quaternary Science Reviews 58, $18-29$.

McMillan, A.A., Browne, M.A.E., 1983. Glacitectonic structures at Bellshill, east end of Glasgow. Quaternary Newsletter 40, 1-6.

Merritt, J.W., 1992. The high-level marine shell-bearing deposits of Clava, Inverness-shire, and their origin as glacial rafts. Quaternary Science Reviews 11, $759-779$.

Munthe, H., 1897. On the interglacial submergence of Great Britain. Bulletin of the Geological Institute of Upsala 13, 369-411.

Nishiizumi, K., Imamura, M., Caffee, M.W., Southon, J.R., Finkel, R.C., Mcaninch, J., 2007. Absolute calibration of Be-10 AMS standards. Nuclear Instruments and Methods in Physics Research B 258, 403-413.

O'Cofaigh, C., Dunlop, P., Benetti, S., 2012. Marine geophysical evidence for Late Pleistocene ice sheet extent and recession off northwest Ireland. Quaternary Science Reviews 44, 147 - 159. 
Peacock, D., 2008. Late Devensian palaeoenvironmental changes in the sea area adjacent to islay, SW Scotland: implications for the deglacial history of the Island. Scottish Journal of Geology 44, $183-190$.

Peacock, J.D., Horne, D.J., Whittaker, J.E., 2012. Late Devensian evolution of the marine offshore environment of western Scotland. Proceedings of the Geologists' Association 123, $419-437$.

Peacock, J.D., Merritt, J.W., 1997. Glacigenic rafting at castle hill, gardenstown, and its significance for the glacial history of northern banffshire, scotland. Journal of Quaternary Science 12, 283-294.

Phillips, E., Merritt, J., 2008. Evidence for multiphase water-escape during rafting of shelly marine sediments at Clava, Inverness-shire, NE Scotland. Quaternary Science Reviews 27, 988 - 1011.

Phillips, W.M., Hall, A.M., Mottram, R., Fifield, L.K., Sugden, D.E., 2006. Cosmogenic 10Be and 26Al exposure ages of tors and errstics, Cairngorm Mountains, Scotland: Timescales for the development of a classic landscape of selective linear glacial erosion. Geomorphology 73, 222-245.

Porter, S.C., 1989. Some geological implications of average Quaternary glacial conditions. Quaternary Research 32, $245-261$.

Rahmstorff, S., 2002. Ocean circulation and climate during the past 120,000 years. Nature 419, $207-214$.

Retzlaff, R., Bentley, C., 1993. Timing of stagnation of Ice Stream C, West Antarctica, from short-pulse radar studies of buried surface crevasses. Journal of Glaciology 39, 553-561.

Ross, N., Bingham, R., Corr, H.F.J., Ferraccioli, F., Jordan, T.A., Brocq, A.L., Rippin, D.M., Young, D., Blakenship, D.D., Siegert, M.J., 2012. Steep reverse bed at the grounding line of the Weddell Sea sector in West Antarctica. Nature Geoscience 5, 393-396.

Ross, N., Jordan, T.A., Bingham, R.G., Corr, H.F.J., Ferraccioli, F., Le Brocq, A., Rippin, D.M., Wright, A.P., Siegert, M.J., 2013. The Ellsworth Subglacial Highlands: inception and retreat of the West Antarctic Ice Sheet. Gological Society of America Bulletin in press.

Ross, N., Siegert, M., Woodward, J., Smith, A., Corr, H., Bentley, M., Hindmarsh, R., King, E., Rivera, A., 2011. Holocene stability of the Amundsen-Weddell ice divide, West Antarctica. Geology 39, 935-938.

Salt, K.E., Evans, D.J.A., 2004. Scottish Landform Example 32: superimposed subglacially streamlined landforms of southwest Scotland. Scottish Geographical Journal 14, 133-147.

Scourse, J.D., Haapaniemi, A.I., Colmenero-Hidalgo, E., Peck, V.L., Hall, I.R., Austin, W.E.N., Knutz, P.C., Zahn, R., 2009. Growth, dynamics and deglaciation of the last British-Irish ice sheet: the deep-sea ice-rafted detritus record. Quaternary Science Reviews 28, 3066 - 3084.

Shennan, I., Bradley, S., Milne, G., Brooks, A., Bassett, S., Hamilton, S., 2006. Relative sea-level changes, glacial isostatic modelling and ice-sheet reconstructions from the British Isles since the Last Glacial Maximum. Journal of Quaternary Science 21, 585-599.

Sinclair, W., 1911. The relationship betwen the raised beach and the boulder clay of the west coast of Kintyre. Transactions of the Geological Society of Glasgow 14, 170.

Sissons, J., 1967. The evolution of Scotland's scenery. Oliver and Boyd, Edinburgh.

Sissons, J.B., 1981. British shore platforms and ice-sheets. Nature 291, 473-475.

Smith, A.M., Murray, T., Nicholls, K.W., Makinson, K., Adalgeirsdóttir, G., Behar, A.E., Vaughan, D.G., 2007. Rapid erosion, drumlin formation, and changing hydrology beneath an Antarctic ice stream. Geology 35. 
Smith, M.J., Clark, C.D., 2005. Methods for the visualization of digital elevation models for landform mapping. Earth Surface Processes and Landforms 30, 885-900.

Stokes, C.R., Clark, C.D., Storrar, R., 2009. Major changes in ice stream dynamics during deglaciation of the north-western margin of the laurentide ice sheet. Quaternary Science Reviews 28, 721 - 738 .

Stone, J., 2000. Air pressure and cosmogenic isotope production. Journal of Geophysical research 105 (B10), 2375323759.

Sugden, D.E., 1968. The selectivity of glacial erosion in the Cairngorm Mountains, Scotland. Transactions of the Institute of British Geographers 45, 79-92.

Sutherland, D.G., 1981. The high-level marine shell beds of Scotland and the build-up of the last Scottish ice sheet. Boreas 10, 247-54.

Synge, F.M., Stephens, N., 1966. Late- and post-glacial shorelines, and ice limits in Argyll and north-east Ulster. Transactions of the Institute of British Geographers 39, 101-25.

Trommelen, M.S., Ross, M., Campbell, J.E., 2012. Glacial terrain zone analysis of a fragmented paleoglaciologic record, southeast Keewatin sector of the Laurentide Ice Sheet. Quaternary Science Reviews 40, 1 - 20.

Tyrrell, G.W., 1928. The Geology of Arran. Memior of the Geological Survey, HMSO, Edinburgh.

Watson, R.B., 1864. On the great drift beds with shells in the south of Arran. Transactions of the Royal Society of Edinburgh 23, 523-546.

Xu, S., Dougans, A., Freeman, S., Schnabel, C., Wilcken, K., 2010. Improved Be-10 and Al-26 AMS with a 5 MV spectrometer. Nuclear Instruments and Methods in Physics Research B 268, 736-738. 


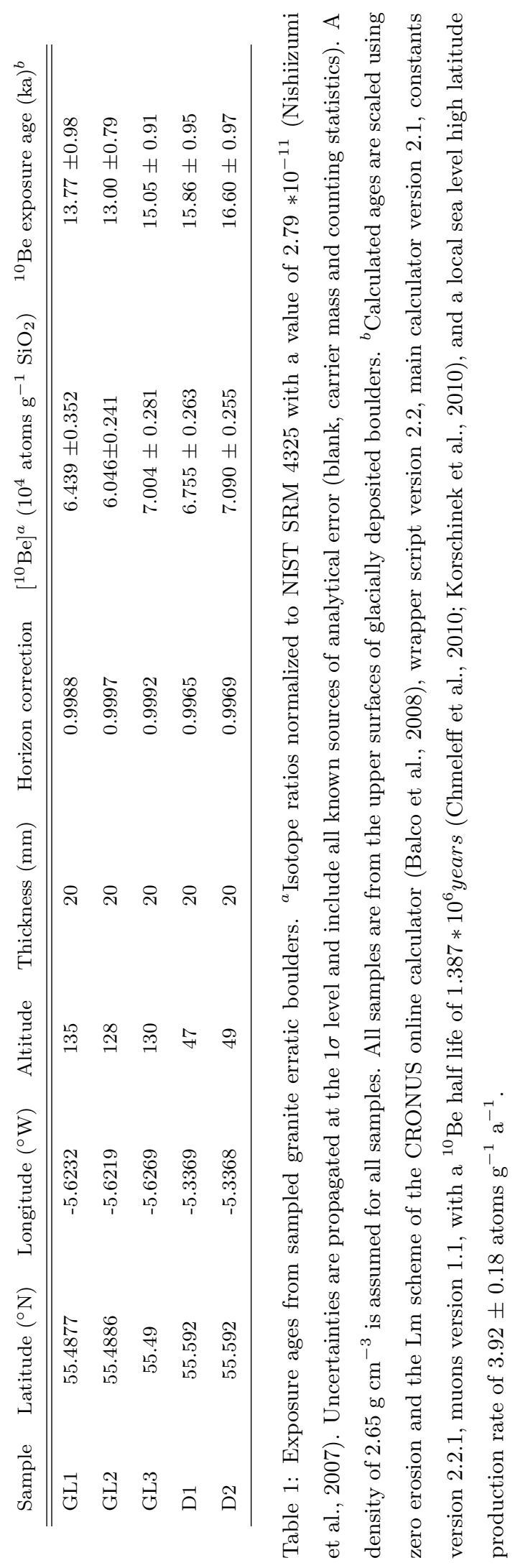




\begin{tabular}{lccccc}
\hline \multirow{2}{*}{ Flow set } & \multicolumn{3}{c}{ Elongation ratio } & \multicolumn{2}{c}{ Centroid elevation $(\mathrm{m})$} \\
\cline { 2 - 6 } & Range & Mean & SD & Range & Median \\
\hline $1(\mathrm{n}=86)$ & $1.6-5.8$ & 3.2 & 0.9 & $11-335$ & 122 \\
$2(\mathrm{n}=76)$ & $2.1-7.7$ & 3.4 & 1.3 & $31-363$ & 81 \\
$3(\mathrm{n}=52)$ & $2.1-7.7$ & 3.8 & 1.1 & $28-167$ & 91 \\
$4 \mathrm{a}(\mathrm{n}=108)$ & $1.2-4.9$ & 2.7 & 0.9 & $17-154$ & 81 \\
$4 \mathrm{~b}(\mathrm{n}=62)$ & $1.9-4.7$ & 3.1 & 0.7 & $25-99$ & 59 \\
$5(\mathrm{n}=180)$ & $1.6-5.4$ & 3.4 & 0.7 & $15-312$ & 85 \\
\hline
\end{tabular}

Table 2: Streamlined bedform summary statistics. 'Centriod' refers to the middle point of each streamlined bedform. 


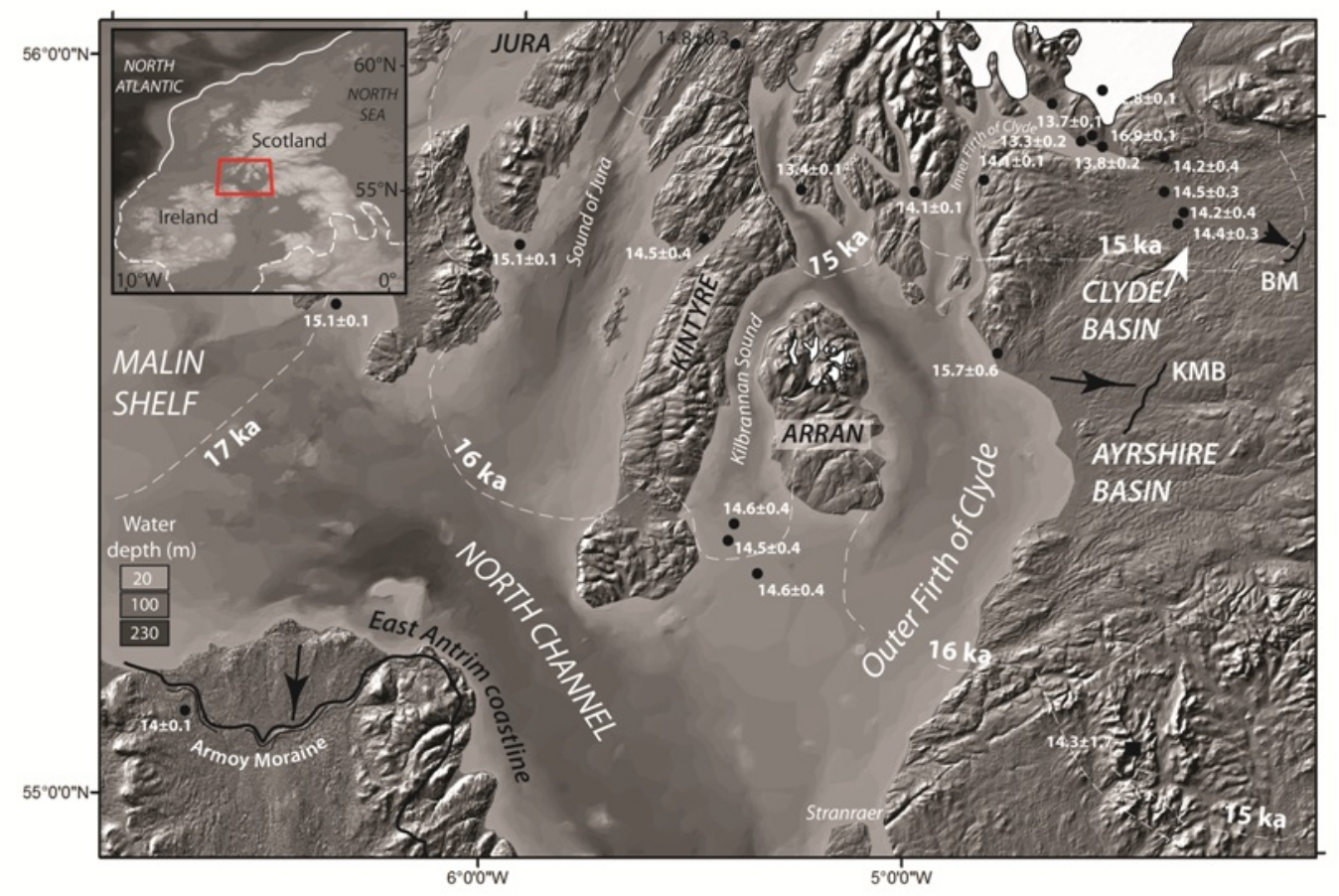

Figure 1: Fig. 1. Location of the Kintyre Peninsula and Island of Arran, between the fjord coastline of western Scotland and the Malin Shelf to the west. KMB: Kilmarnock moraine belt; BM: Blantyreferme moraine. 15, 16, and $17 \mathrm{ka}$ ice retreat isochrones are taken from Clark et al. (2012). Calibrated radiocarbon ages (black circles) from the database of Hughes et al. (2011) and from Peacock et al. (2012). Areas in white show maximum glacier extent during the Younger Dryas (12.9-11.7 ka BP), based on Clark et al. (2004) and Ballantyne (2007). Hill-shaded surface models built from Intermap Technologies NEXTMap Britain elevation data and Land and Property Services mapping data (Crown Copyright). Bathymetry from BGS Digbath-250 dataset. Inset: Location within a national context. The white line gives the approximate extent of the last BIIS, based on Bradwell et al. (2008) (solid line) and Clark et al. (2012) (dashed line). 

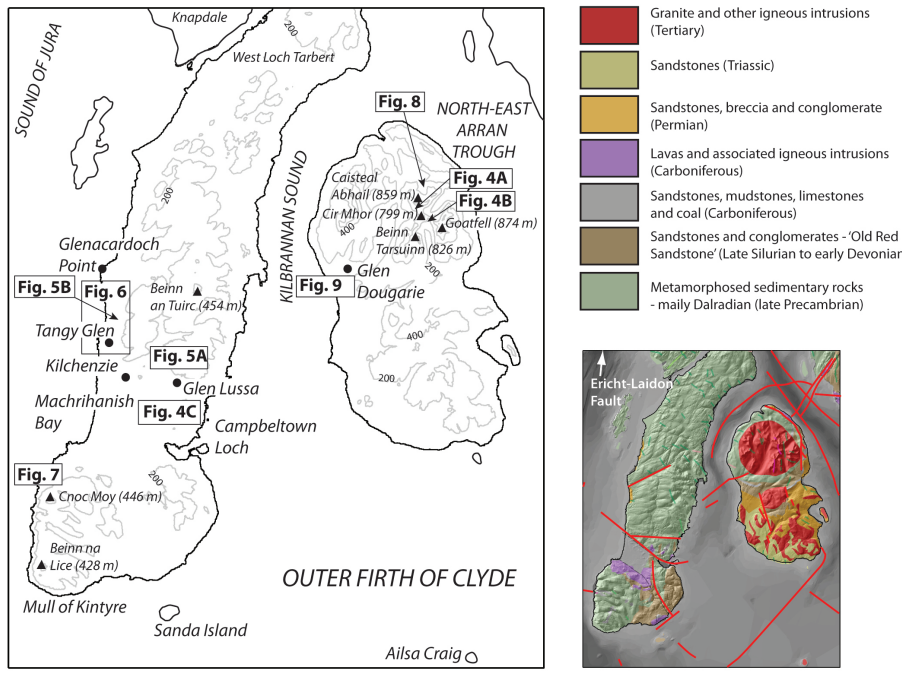

Figure 2: Fig. 2. Topography and simplified bedrock geology of Kintyre and Arran. Red lines on the geology map indicate faults. 

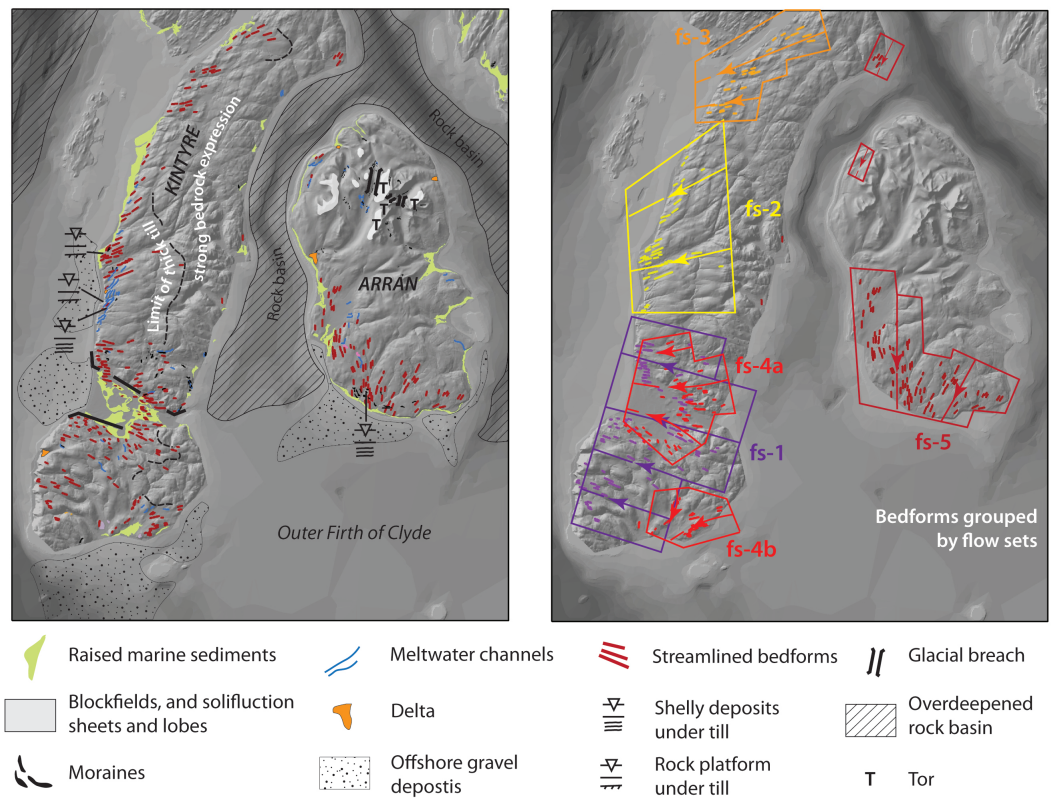

Figure 3: Fig. 3. Glacial geomorphology of Kintyre and Arran. Distribution of raised marine sediments and offshore gravel deposits compiled from published BGS maps. Right hand panel shows streamlined bedforms grouped into flow sets (fs) (Table 2). Hill-shaded surface models built from Intermap Technologies NEXTMap Britain elevation data.
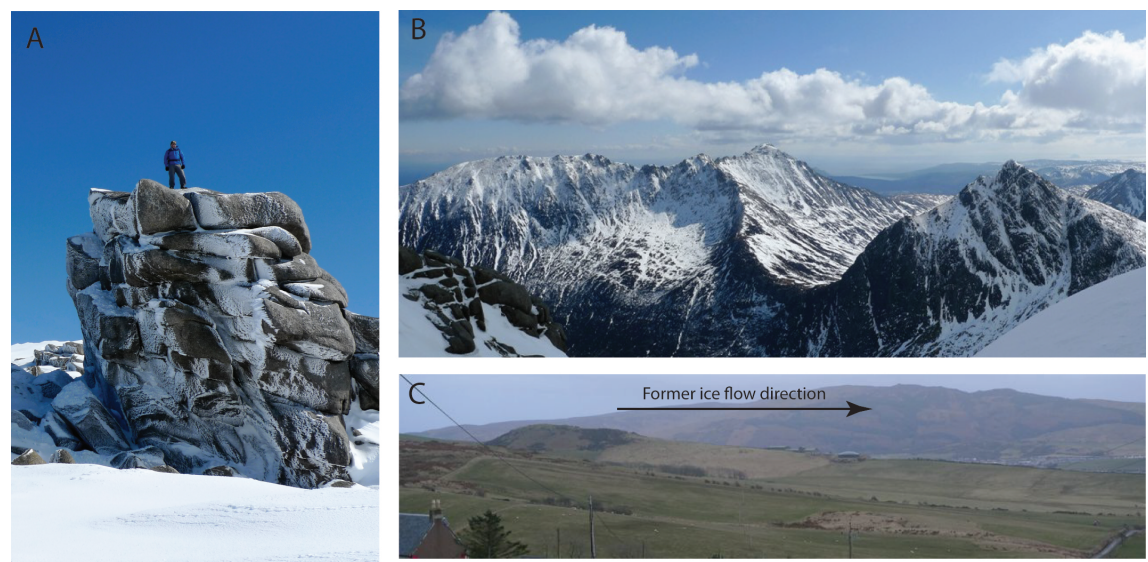

Figure 4: Fig. 4. Examples of landforms that were preserved, modified or created under the last ice sheet. A: tor on Caisteal Abhail, northern Arran. B: North-south directed glacial breach, northern Arran.C; Elongated crag-and -tail, southern Kintyre. 


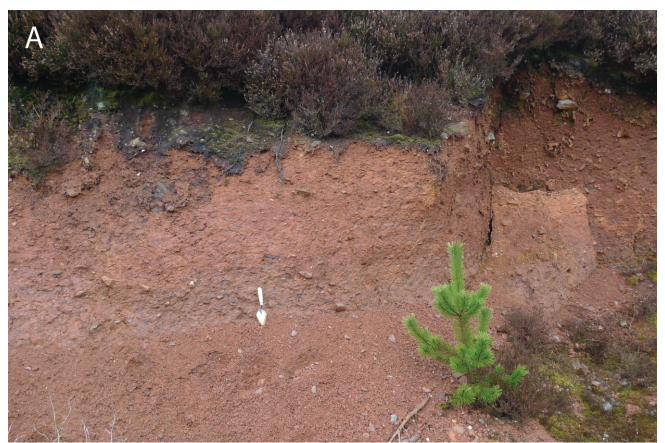

B

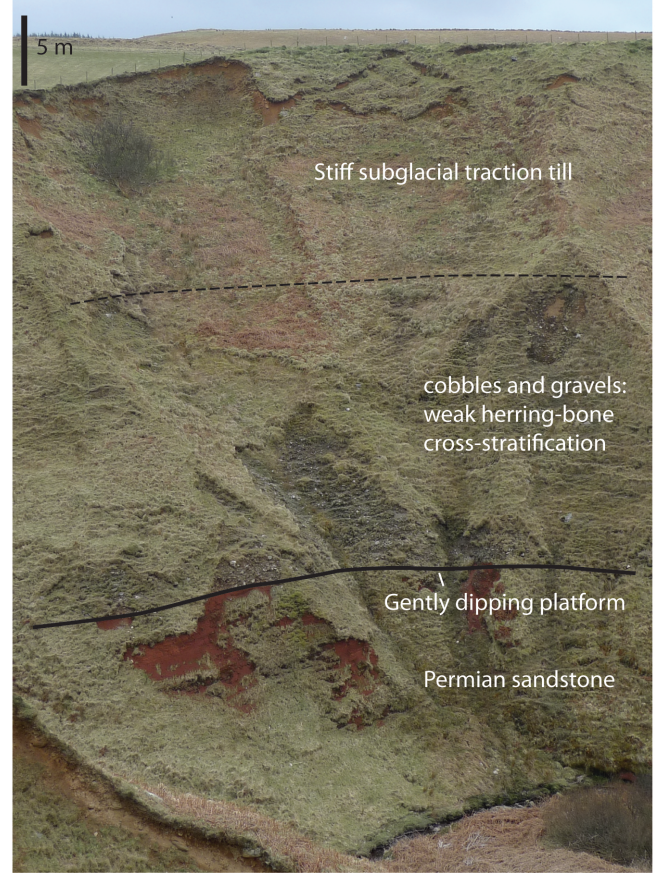

Figure 5: Fig. 5. Subglacial sediments exposed on western Kintyre. A: stiff, red subglacial traction till, which forms thick sequences over the western central part of Kintyre. B: $15 \mathrm{~m}$ of subglacial traction till overlying weakly, herring bone cross-stratified gravels, interpreted as beach deposits. These rest on a platform cut into Permian sandstones at approximately $18 \mathrm{~m}$ a.s.l, only a few metres higher than the pre-last glacial cycle rock shore platform described by Gray $(1978,1993)$ at Glenacardoch Point to the north. 


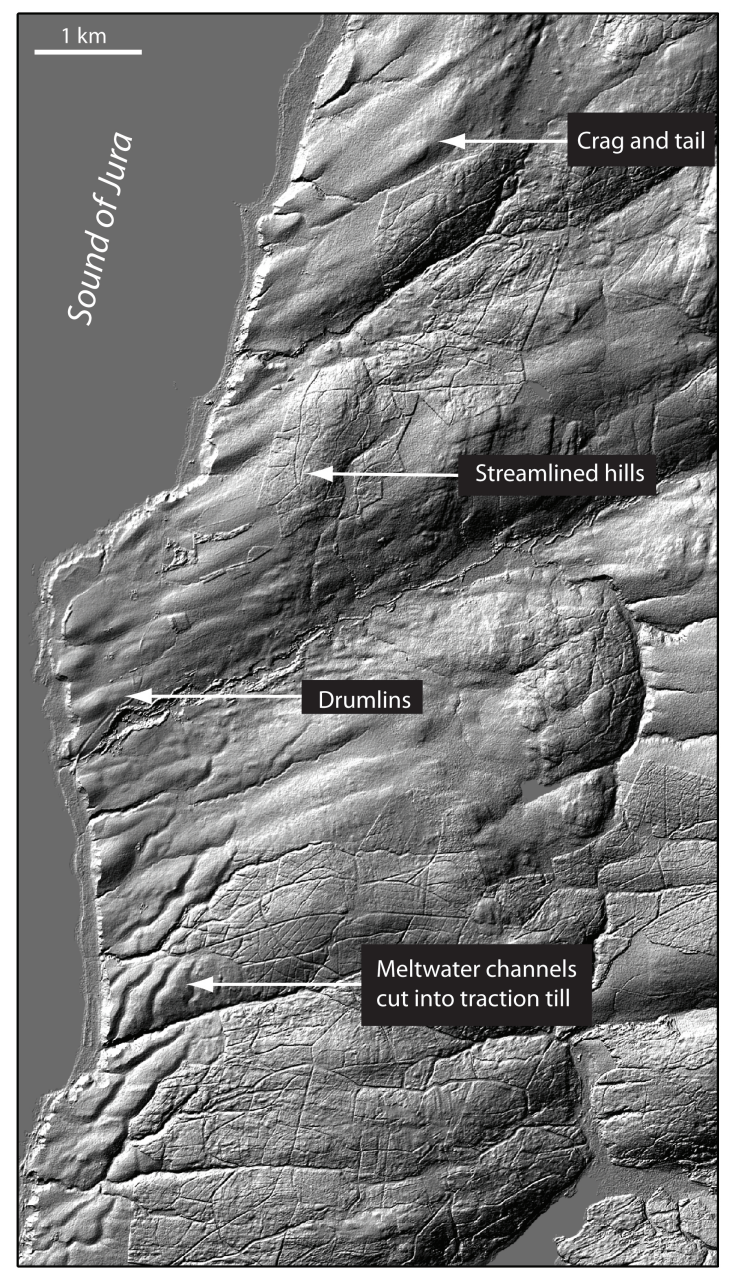

Figure 6: Fig. 6. Meltwater channels (bottom left of image) dissecting west-south-west streamlined bedforms formed in subglacial till, western Kintyre. Hill-shaded surface models built from Intermap Technologies NEXTMap Britain elevation data. 

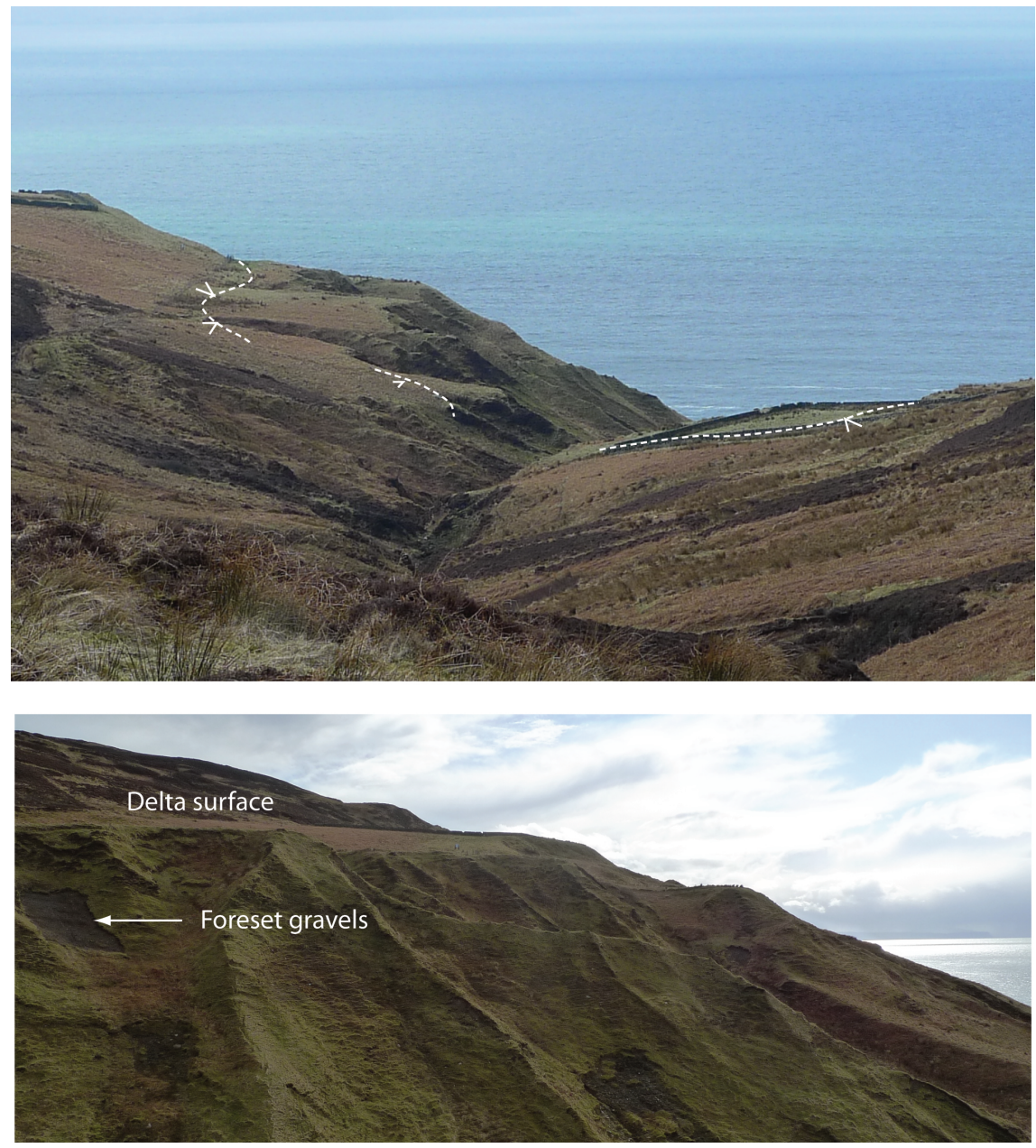

Figure 7: Fig. 7. Perched delta at an elevation of $130 \mathrm{~m}$ a.s.l. on south-western Kintyre. The delta formed as water ponded against an outlet glacier flowing along the low ground offshore.

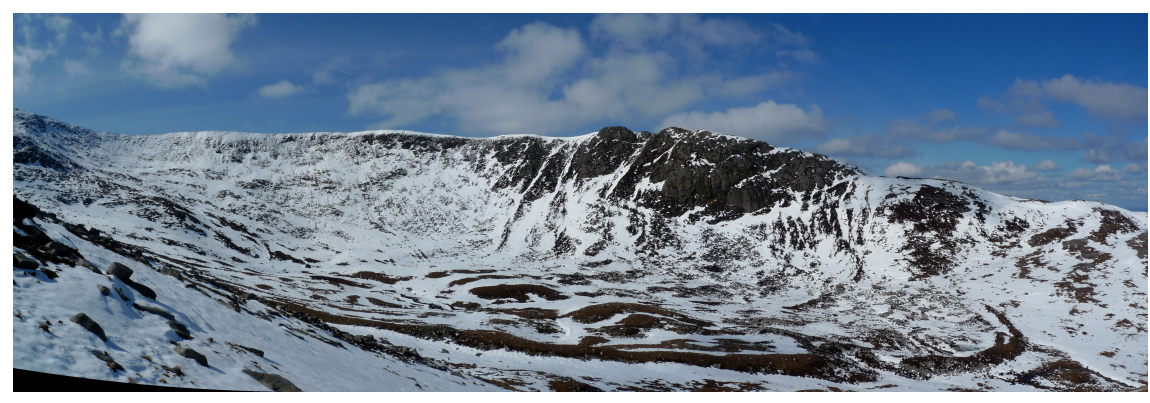

Figure 8: Fig. 8. Clear boulder moraine at the head of north Glen Sannox, Arran. This moraine probably formed during a Younger Dryas glacier advance. 


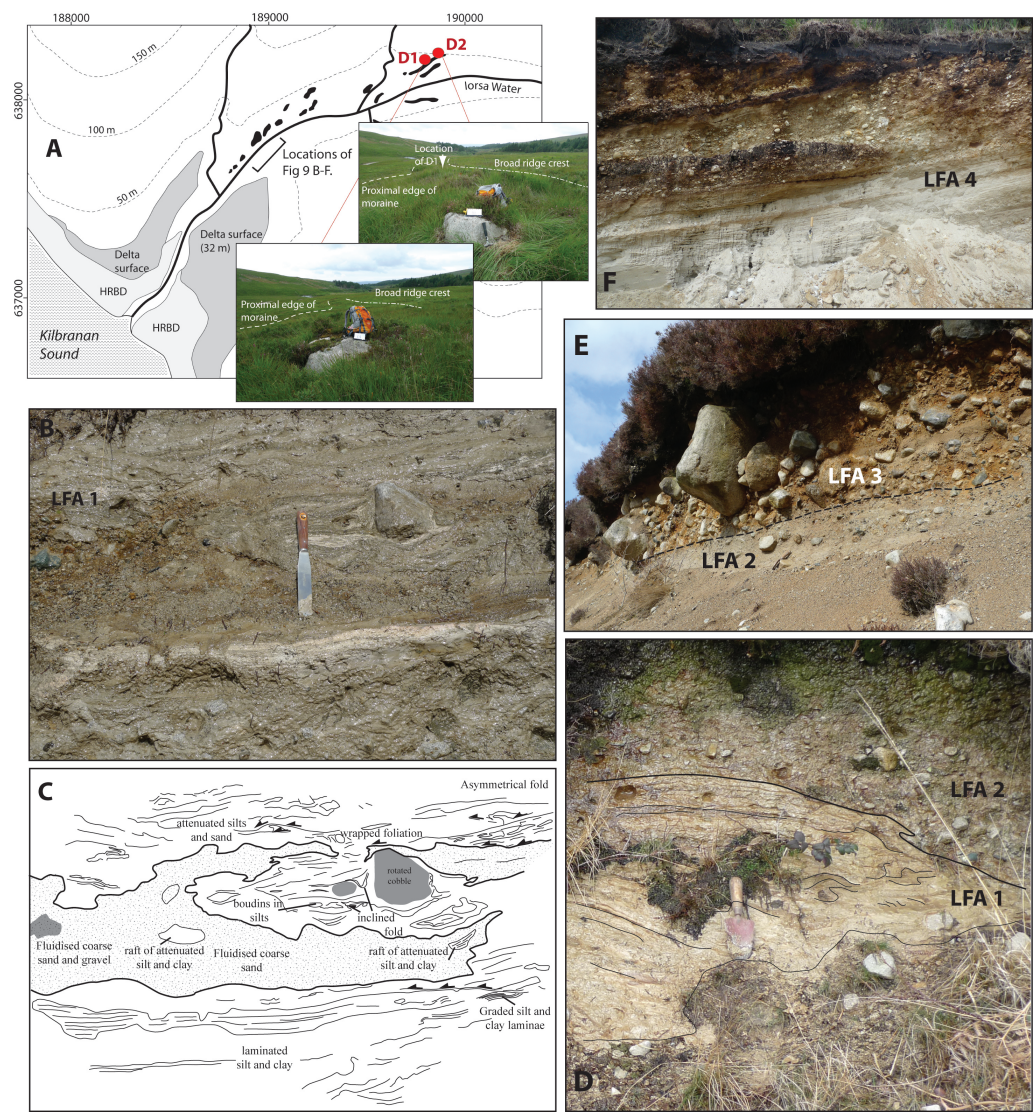

Figure 9: Fig. 9. Sediment exposures at the mouth of Glen Dougarie, Arran. A: Geomorphological context. Filled black polygons indicate the position of moraines. The locations of samples D1 and D2 are shown. HRBD: Holocene raised beach deposits. B: Photograph of lithofacies association 1 (glacitectonite). C: Line drawing highlighting deformation structures in lithofacies association 1. D. Section revealing the contact between lithofacies association 1 and lithofacies association 2 (subglacial till). E: Lithofacies association 3 (moraine). F lithofacies association 4 (delta foresets). 

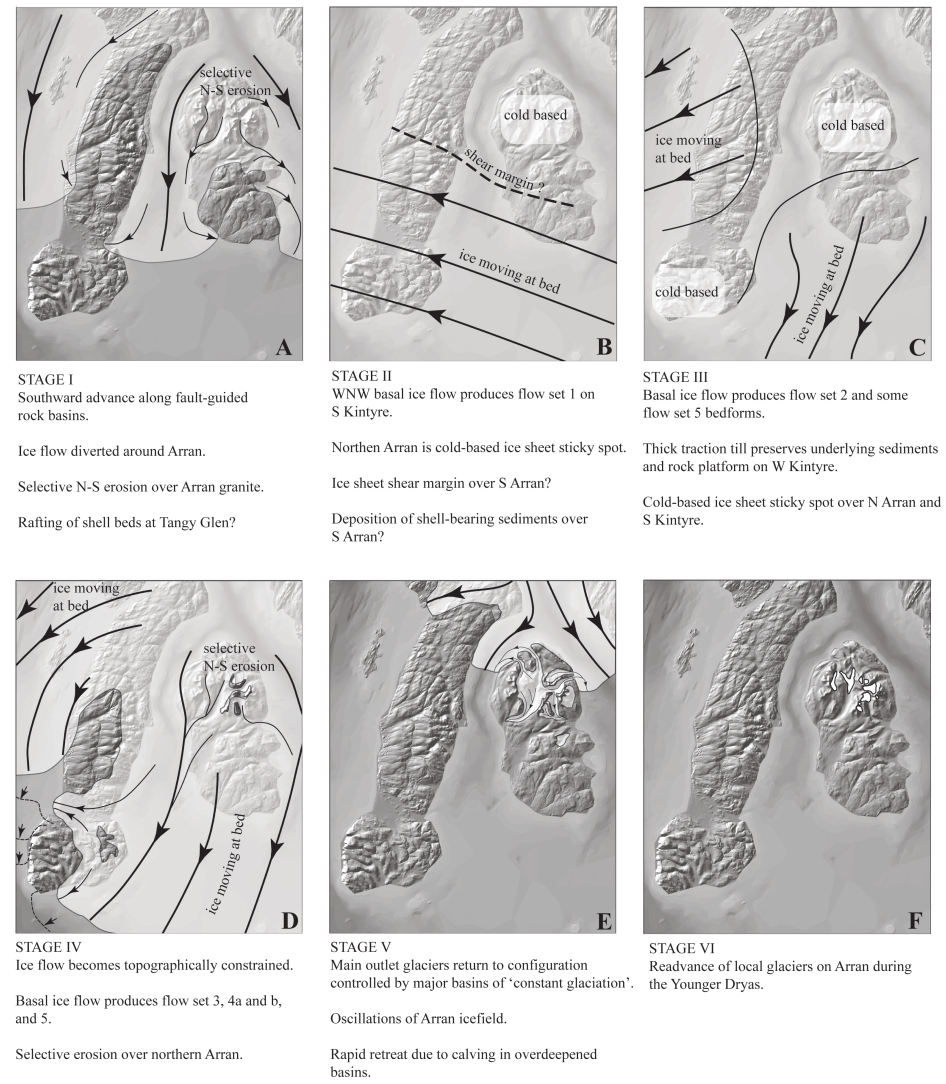

Figure 10: Fig. 10. Interpretation of ice sheet stages that affected the landscape of Kintyre and Arran. 

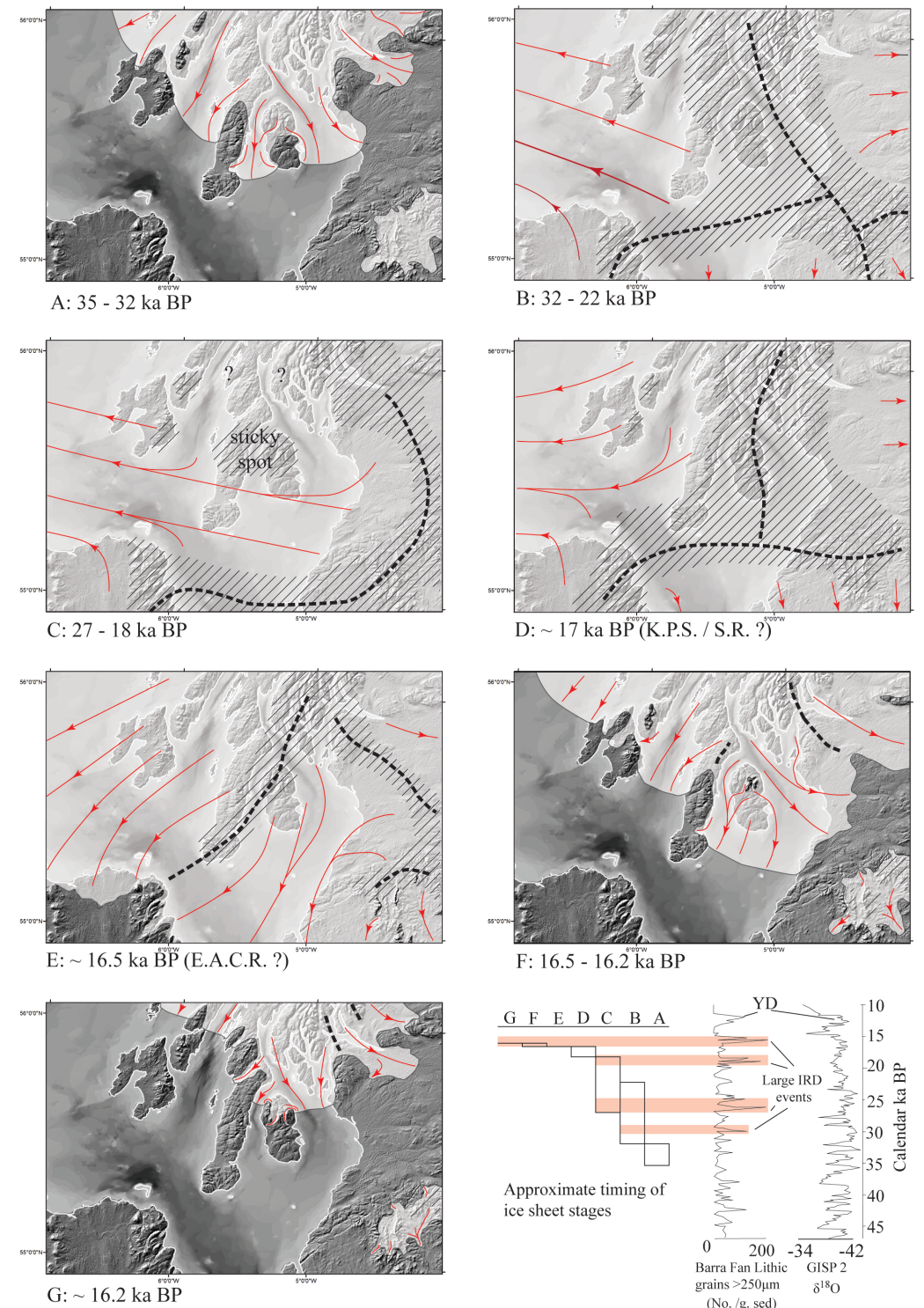

Figure 11: Fig. 11. Growth and decay of the last BIIS over western Scotland, the North Channel, and north-east Ireland. This reconstruction is synthesised from work presented here and existing published research (Salt and Evans, 2004; Dunlop et al., 2010; Finlayson et al., 2010; Livingstone et al., 2012; Clark et al., 2012; McCabe and Williams, 2012).Diagonal shading indicates probable cold-based ice. Dashed line denotes suggested ice divides. KPS: Killard Point Stadial; S.R: Scottish Readvance; E.A.C.R.: East Antrim Coastal Readvance. Lower right: Lithic grains observed in core MD95-2006 (Barra Fan) and GISP 2 Oxygen isotope record, from Knutz et al. (2001). 

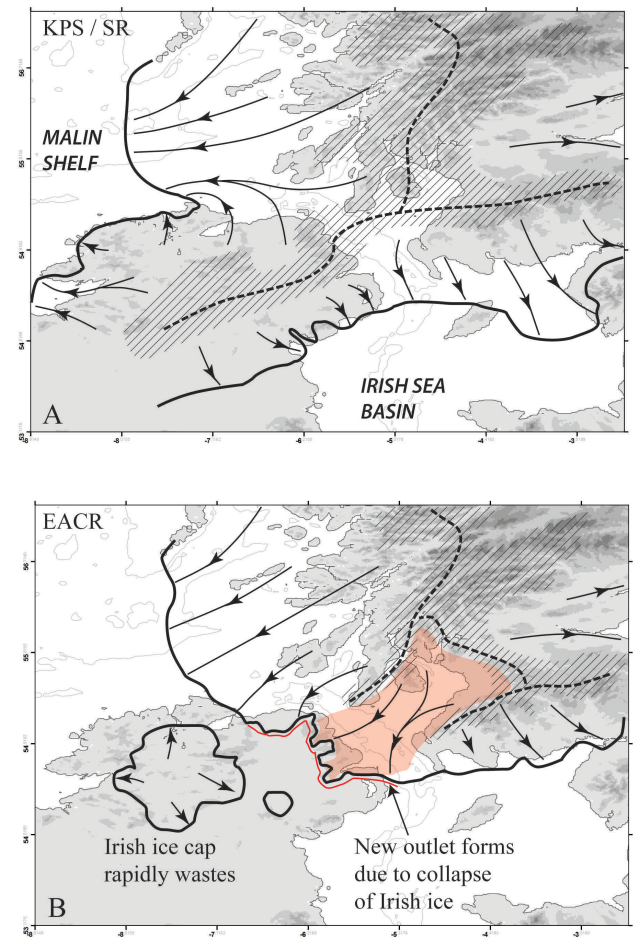

Figure 12: Fig. 12. Interpretation of ice sheet / ice cap configuration prior to and during the East Antrim Coastal Readvance. KPS: Killard Point Stadial; SR: Scottish Readvance; EACR: East Antrim Coastal Readvance. Diagonal shading indicates probable cold-based ice. Dashed line denotes suggested ice divides. 